\title{
The Green Edge cruise: Understanding the onset, life and fate of the Arctic phytoplankton spring bloom.
}

Flavienne Bruyant ${ }^{1,2}$, Rémi Amiraux ${ }^{1,2,3}$, Marie-Pier Amyot ${ }^{1}$, Philippe Archambault ${ }^{1,2}$, Lise Artigue ${ }^{4}$, Lucas Barbedo de Freitas ${ }^{2,5}$, Guislain Bécu ${ }^{1,2}$, Simon Bélanger ${ }^{2,5}$, Pascaline Bourgain ${ }^{6}$, Annick Bricaud ${ }^{7}$, 5 Etienne Brouard ${ }^{1}$, Camille Brunet ${ }^{8}$, Tonya Burgers ${ }^{9}$, Danielle Caleb ${ }^{10}$, Katrine Chalut ${ }^{11}$, Hervé Claustre ${ }^{7}$, Véronique Cornet-Barthaux ${ }^{8}$, Pierre Coupel ${ }^{8}$, Marine Cusa ${ }^{12}$, Fanny Cusset ${ }^{1}$, Laeticia Dadaglio ${ }^{13}$, Marty Davelaar $^{10}$, Gabrièle Deslongchamps ${ }^{1,2}$, Céline Dimier ${ }^{7}$, Julie Dinasquet ${ }^{13}$, Dany Dumont ${ }^{2,14}$, Brent Else $^{15}$, Igor Eulaers ${ }^{16}$, Joannie Ferland ${ }^{1,2}$, Gabrielle Filteau ${ }^{1,2}$, Marie-Hélène Forget ${ }^{1}$, Jérome Fort ${ }^{17}$, Louis Fortier $^{1,2, \sharp}$, Martí Galí Tapías ${ }^{1,18}$, Morgane Gallinari ${ }^{3}$, Svend-Erik Garbus ${ }^{16}$, Nicole Garcia ${ }^{8}$, Catherine

10 Gérikas Ribeiro ${ }^{19,20}$, Coline Gombault ${ }^{21}$, Priscilla Gourvil ${ }^{22}$, Clemence Goyens ${ }^{23}$, Cindy Grant ${ }^{1,2}$, PierreLuc Grondin ${ }^{1,2}$, Pascal Guillot',21, Sandrine Hillion ${ }^{3}$, Rachel Hussher ${ }^{2}$, Fabien Joux ${ }^{13}$, Hannah JoyWarren $^{24}$, Gabriel Joyal ${ }^{1,2}$, David Kieber ${ }^{25}$, Augustin Lafond ${ }^{8}$, José Lagunas ${ }^{1,2}$, Patrick Lajeunesse ${ }^{1}$, Catherine Lalande ${ }^{1,2}$, Jade Larivière ${ }^{1,2}$, Florence Le Gall ${ }^{19}$, Karine Leblanc ${ }^{8}$, Mathieu Leblanc ${ }^{1,2}$, Justine Legras $^{3}$, Keith Lévesque ${ }^{21}$, Kate-M. Lewis ${ }^{24}$, Edouard Leymarie ${ }^{7}$, Aude Leynaert ${ }^{3}$, Thomas Linkowski ${ }^{21}$,

15 Martine Lizotte ${ }^{1,2}$, Adriana Lopes dos Santos ${ }^{26}$, Claudie Marec ${ }^{1,27}$, Dominique Marie ${ }^{19}$, Guillaume Massé $^{1}$, Philippe Massicotte ${ }^{1,2}$, Atsushi Matsuoka ${ }^{1,28}$, Lisa A. Miller ${ }^{10}$,Sharif Mirshak ${ }^{29}$, Nathalie Morata $^{3,12}$, Brivaela Moriceau ${ }^{3}$, Philippe-Israël Morin ${ }^{1,2}$, Simon Morisset ${ }^{21}$, Anders Mosbech ${ }^{16}$, Alfonso Mucci $^{30}$, Gabrielle Nadai ${ }^{1,2}$, Christian Nozais ${ }^{11}$, Ingrid Obernosterer ${ }^{13}$, Thimoté Paire ${ }^{1}$, Christos Panagiotopoulos $^{8}$, Marie Parenteau ${ }^{1,2}$, Noémie Pelletier ${ }^{11}$, Marc Picheral ${ }^{7}$, Bernard Quéguiner ${ }^{8}$, Patrick

20 Raimbault $^{8}$, Joséphine Ras ${ }^{7}$, Eric Rehm ${ }^{1,2}$, Llúcia Ribot Lacosta ${ }^{1,31}$, Jean-François Rontani ${ }^{8}$, Blanche Saint-Béat ${ }^{1,32}$, Julie Sansoulet ${ }^{1}$, Noé Sardet ${ }^{29}$, Catherine Schmechtig ${ }^{33}$,Antoine Sciandra ${ }^{7}$, Richard Sempéré ${ }^{8}$, Caroline Sévigny ${ }^{2,14}$, Jordan Toullec ${ }^{3}$, Margot Tragin ${ }^{19}$, Jean-Éric Tremblay ${ }^{1,2}$, Annie-Pier Trottier $^{1}$, Daniel Vaulot ${ }^{19,26}$, Anda Vladoiu ${ }^{34,35}$, Lei Xue ${ }^{25}$, Gustavo Yunda-Guarin ${ }^{1,2}$ and Marcel Babin ${ }^{1}$

${ }^{1}$ Takuvik, LMR CNRS/Université Laval, Québec G1V 0A6, QC, Canada

$25{ }^{2}$ Québec-Océan, Université Laval, Québec G1V 0A6, QC, Canada

${ }^{3}$ LEMAR, Univ Brest, CNRS, IRD, Ifremer, 29280 Plouzane, France

${ }^{4}$ LEGOS, University of Toulouse, CNRS, CNES, IRD, UPS, 31400 Toulouse, France

${ }^{5}$ Département de Biologie, Chimie et Géographie (groupes BORÉAS et Québec-Océan), Université du Québec à Rimouski, 300 allée des Ursulines, Rimouski G5L 3A1, QC, Canada

$30{ }^{6}$ Société AVUNGA, Lars en Vercors, France

${ }^{7}$ Laboratoire d'Océanographie de Villefranche, UMR7093, CNRS/Sorbonne Université, Villefranche-sur-Mer, France

${ }^{8}$ Mediterranean Institute of Oceanography (MIO), Aix-Marseille Université, Université de Toulon, CNRS, IRD, UM110, 13288 Marseille, France

${ }^{9}$ Centre for Earth Observation Science, University of Manitoba, Winnipeg MB, Canada

$35{ }^{10}$ Institute of Ocean Sciences, Fisheries and Oceans Canada, Sidney BC, Canada.

${ }^{11}$ Québec-Océan, Département de biologie, chimie et géographie, Université du Québec à Rimouski QC, Canada

${ }^{12}$ Akvaplan-niva, Fram Centre for Climate and the Environment, Troms $\varnothing$, Norway

13 Laboratoire d'Océanographie Microbienne (LOMIC), UMR7621, CNRS/ Sorbonne Université, Observatoire Océanologique de Banyuls-sur-mer, France

$40 \quad{ }^{14}$ Institut des sciences de la mer de Rimouski, Université du Québec à Rimouski, QC, Canada

${ }^{15}$ Department of Geography, University of Calgary, Calgary T2N 1N4, AB, Canada

${ }^{16}$ Department of Biosciences - Arctic Environment, Aarhus University, Denmark

${ }^{17}$ Littoral Environnement et Sociétés, UMR7266, CNRS/Université de La Rochelle, France

${ }^{18}$ Barcelona Supercomputing Center (BSC), Barcelona, Spain.

$45{ }^{19}$ ECOMAP, UMR7144, CNRS/Sorbonne Université, Station Biologique de Roscoff, France

${ }^{20}$ GEMA Center for Genomics, Ecology \& Environment, Faculty of Sciences, Universidad Mayor, Santiago, Chile

${ }^{21}$ Amundsen Science, Université Laval, Québec QC, Canada

${ }^{22}$ Roscoff Culture Collection, FR2424 CNRS/Université Sorbonne, Station Biologique, Roscoff France.

${ }^{23}$ Operational Directorate Natural Environment, Royal Belgian Institute of Natural Sciences (RBINS), 29 Rue Vautierstraat, 501000 Brussels, Belgium

${ }^{24}$ Department of Earth System Science, Stanford University, Stanford, CA 94305, USA

${ }^{25}$ Department o Chemistry, College of environmental sciences and forestry, State University of New York, Syracuse, NY 13210, USA

${ }^{26}$ Asian School of the Environment, Nanyang Technological University, 50 Nanyang Avenue, Singapore 639798, Singapore

${ }^{27}$ Institut Universitaire Européen de la Mer, UMS3113, CNRS/Univ. Brest, Plouzane, France 
${ }^{28}$ School of Marine Science and Ocean Engineering (SMSOE), Institute for the Study of Earth, Oceans, and Space (EOS) University of New Hampshire, Durham, USA

${ }^{29}$ Société Parafilm, Montréal QC, Canada

${ }^{30}$ GEOTOP and Department of Earth and Planetary Sciences, McGill University, Montréal QC, Canada

$60{ }^{31}$ Balearic Islands Coastal Observing and Forecasting System, SOCIB, 07122, Edificio Naorte, Bloque A, Parc Bit, Palma de Mallorca, Spain

${ }^{32}$ Dyneco Pelagos, IFREMER, BP70, 29280 Plouzané, France.

${ }^{33}$ OSU Ecce-Terra, UMS3455, CNRS/Sorbonne Université, PARIS Cedex 5, France

${ }^{34}$ LOCEAN-IPSL, UMR7159, CNRS/IRD/MNHN/Sorbonne Université, 75005 Paris, France

$65{ }^{35}$ Applied Physics Laboratory, University of Washington, Seattle, WA 98105, USA

¿ Deceased.

Correspondence to: Flavienne Bruyant (flavienne.bruyant@takuvik.ulaval.ca)

Abstract. The Green Edge project was designed to investigate the onset, life and fate of a phytoplankton spring bloom (PSB) in the Arctic Ocean. The lengthening of the ice-free period and the warming of seawater, amongst other factors, have induced major changes in arctic ocean biology over the last decades. Because the PSB is at the base of the Arctic Ocean food chain, it is crucial to understand how changes in the arctic environment will affect it. Green Edge was a large multidisciplinary collaborative project bringing researchers and technicians from 28 different institutions in seven countries, together aiming at understanding these changes and their impacts into the future. The fieldwork for the Green Edge project took place over two years (2015 and 2016) and was carried out from both an ice-camp and a research vessel in the Baffin Bay, canadian arctic. This paper describes the sampling strategy and the data set obtained from the research cruise, which took place aboard the Canadian Coast Guard Ship (CCGS) Amundsen in spring 2016. The dataset is available at https://doi.org/10.17882/59892 (Massicotte et al., 2019a).

\section{Introduction}

The Arctic Ocean is currently experiencing unprecedented environmental changes. The increase of the summer ice-retreat

lengthens the phytoplankton growing season but also increases the area of the marginal ice zone (MIZ). If trends are maintained, the MIZ may cover the entire Arctic Ocean as early as twenty years from now (Meredith et al., 2019). Ice edge blooms represent much of the annual phytoplankton primary production in the Arctic Ocean (Perrette et al., 2011; Ardyna et al., 2013), and their current phenology is relatively well known (Wassmann and Reigstad, 2011; Leu et al., 2015). However, we currently do not know how precisely primary production will respond to climate changes. The overarching goal of Green Edge was to understand the processes that control an arctic PSB as it expands northward, and to determine its fate through the investigation of related carbon fluxes. This study was also motivated by the discovery that PSBs can and do occur underneath the ice (Arrigo et al., 2014) despite the limited amounts of underice available light (Mundy et al., 2009; Arrigo et al., 2014; Lowry et al., 2014; Assmy et al., 2017, Randelhoff et al., 2019). Field studies for the Green Edge project were carried out in 2015 and 2016 at an ice-camp located on landfast sea ice close to Qikiqtarjuaq (NU, Canada). Additionally, during spring 2016, a cruise aboard CCGS Amundsen was conducted in Baffin Bay. As explained in Randelhoff et al. (2019), Baffin Bay is both relatively easy to access and represents an ideal framework for this study, because environmental conditions are representative of what is observed at the pan-arctic scale. Particularly, the warm Greenland current flowing north on the Greenland side, and colder waters on the Canadian side flowing south (Baffin Island current) induce an evenly retreating ice edge, allowing a straightforward sampling strategy. Here, we present an overview of the dataset gathered during this cruise.

\section{Study area, sampling strategy and ship-based operations}

For logistical reasons, the cruise was divided into two legs. Leg 1A started on June 3rd in Québec City, ended on June 23rd in Qikiqtarjuaq (NU), and included one week of transit to the study zone. Leg 1B started on June 23rd in Qikiqtarjuaq and ended 
in Iqaluit (NU) on July 14th. During the five-week period spent in the Baffin Bay, the ship crossed the MIZ, from open waters (in the east) to sea ice-covered areas (in the west) and back again following latitudinal transects. A total of seven transects were covered between $68.0^{\circ} \mathrm{N}$ and $70.5^{\circ} \mathrm{N}$ (Fig. 1A). Three transects were covered during Leg $1 \mathrm{~A}\left(68.5^{\circ} \mathrm{N}\right.$ to $\left.69.0^{\circ} \mathrm{N}\right)$ and four during leg $1 \mathrm{~B}\left(68.0^{\circ} \mathrm{N}\right.$ and $69.5^{\circ} \mathrm{N}$ to $\left.70.5^{\circ} \mathrm{N}\right)$. For each transect, stations were separated by six nautical miles (approximately $11 \mathrm{~km}$ ) to obtain a relatively high spatial resolution. Fifteen to twenty-five stations were sampled within each transect, for a total of 144 stations visited during the campaign.

The activities conducted at each type of station are detailed in Table 1. Briefly, at so-called CTD (Current Temperature Depth) stations, rosette casts did not include seawater collection. The rosette, a Sea-Bird model 32 carousel equipped with twenty-two 12-L Niskin bottles, was geared with multiple sensors (see Table 2 for details). At NUT stations, seawater samples were additionally collected at several depths between 2 and $2000 \mathrm{~m}$ for nutrient analyses. At BASIC stations, the apparent optical properties of seawater were measured using underwater profiling optical instruments. The variables measured at BASIC stations included the concentration of chlorophyll, phytoplankton pigment, particulate carbon and nitrogen, and particulate absorption spectra. Finally, at FULL stations, a suite of measurements was made on seawater samples, and several underwater instruments were deployed as well. Vertical plankton nets geared with a plankton imager, horizontal net trawls, benthic trawls and Ursnel box corers were also deployed at each FULL station. Note that the number of variables measured on seawater samples was significantly larger at FULL stations, where three rosette casts were necessary to cover the demand in water volume, compared with one rosette at BASIC stations (see Table 3). At least one FULL station was sampled in each of the three major domains covered by each transect, namely open waters, the MIZ and the ice-covered area. A schematic synopsis of all operations carried out during the campaign can be found in Fig. 2. During Leg 1B a larger emphasis was placed on collecting ice-cores for analyses and measurements of light propagation through the ice and snow. FULL stations sampled in the ice-covered domain did not include trawling operations.

Our sampling strategy allowed successive crossings of different PSB stages: the early-bloom stage at the western end of transects covered in sea-ice, late- to post-bloom stages at the eastern end of transects in open waters, and full-bloom stage in the middle of transects around the ice edge (see Randelhoff et al., 2019). Between the stations, the ship-track water monitoring system (TSG SBE45 from Sea-Bird, WETStar fluorometer from WetLabs, LiCOR non-dispersive infra-red spectrometer (model Li-7000), Campbell Scientific CR1000 data logger) recorded temperature, salinity, chlorophyll a fluorescence and pCO2 at $7 \mathrm{~m}$ depth continuously when navigating outside the ice pack. A moving vessel profiler (MVP300-1700, AML Oceanographic, Victoria, BC Canada), equipped with a micro CTD (AML), a WetLabs C-Star transmissometer and a WetLabs Eco-FLRTD fluorometer, was deployed in open waters.

To significantly extend the monitoring of the PSB beyond the duration and space covered by the cruise, we deployed four BGC-Argo (Bio-Geo-Chemical-Argo) floats on July 9th. They collected data until November 1st (Fig. 1B), performing a 0$1000 \mathrm{~m}$ profile each day. The ice-specific version of BGC-Argo floats that were deployed, the so-called PRO-ICE, are commercialized by NKE Electronics (France). They carry a typical bio-geochemical payload (Sea-Bird 41 ARGO CTD, Aanderaa optode 4330 Oxygen sensor, Sea-Bird ${ }^{\mathrm{TM}}$ OCR-504 PAR (photosynthetic available radiation) and downwelling radiance sensor (380, 412 and $490 \mathrm{~nm}$ ), Sea-Bird ECO-FLBBCD fluorescence chlorophyll a, colored dissolved organic matter (CDOM), and backscattering sensor and Sea-Bird SUNA nitrate sensor). They also include a 2 way-directional Iridium communication Rudics for data transmission and modification of the sampling pattern and a sea-ice detection system to protect the float from hitting sea ice on ascent (Le Traon et al., 2020; André et al., 2020). Floats are quasi-lagrangian sampling devices following the water mass in which they have been deployed, regardless of ice cover. The 2016 data are available on the following website: http://www.obs-vlfr.fr/proof/ftpv/greenedge/db/DATA/FLOATS/ and http://www.coriolis.eu.org/DataProducts/Data-Delivery.

Two SLOCUM G2 gliders (Teledyne Marine Inc.) were deployed during the cruise from the ship's zodiac either to revisit transects, or in areas that were not visited by the CCGS Amundsen (Fig. 1B). They both carried a similar scientific payload 
and communication system as the BGC-Argo floats, rendering the possibility of inter-calibration (Fig. 3). Gliders were primarily used in the MIZ where a 90-m icebreaker would disturb the fragile hydrological structure of shallow under-ice water masses. Gliders were deliberately directed through the same area as the BGC-Argo floats to compare CTD and optical data from both platforms. Results in Fig. 3 show a good agreement for the data. Gliders travel following a programmed sawtooth pattern, joining pre-defined waypoints. Data and instructions were transmitted both ways via iridium when the glider surfaced. Figure 4 shows an example of the level of detail provided by the gliders when travelling through complex water structures. Representing chlorophyll fluorescence measured over a three-week journey covering almost $500 \mathrm{~km}$, the data show that the glider(s) did travel through both surface blooms and a subsurface chlorophyll maximum between $20-50 \mathrm{~m}$. The data presented in Fig. 4 represents 693,000 chlorophyll fluorescence measurements. These constitute robust results towards the validation of the use of multiple measurement platforms to investigate complex systems.

\section{Data quality control and processing}

More than 150 variables were measured during the Green Edge cruise (Table 3). One of the challenging tasks, when assembling data from a large group of researchers, is to adopt a common frame for spatial and temporal tagging of samples. In particular, geographic positions require a lot of attention and conversion of latitude and longitude into one format (we used decimal degrees east) to ensure data could be easily merged. The concomitant use of local time and coordinated universal time (UTC) during the cruise also represented a challenge. For the Green Edge cruise, an operation logbook was created to keep track of all operations conducted on the ship in sequential order during each day (local time). Each operation was associated with a unique operation ID to which all other data could be referenced. The use of ordinal date (number of days since January first) was used to avoid confusion between European and American date writing conventions. Each cast within a given operation type (CTD/RO for Rosette, AOP for Apparent Optical Properties, etc.) was numbered sequentially, starting from 001, throughout the entire cruise. As a result, any given operation received a unique code which thereafter could be used to merge all the data acquired during that operation.

Different control procedures were adopted to ensure the quality of the data. First, the raw data were screened to eliminate errors originating from the measurement devices, including sensor (systematic or random) errors inherent to measurement procedures and methods. Instrumental pre- and post-calibration corrections were applied when necessary. Statistical summaries such as average, standard deviation and range were computed to detect and remove anomalous values in the data. Then, data were checked for duplicates and remaining outliers. Once raw measurements were cleaned, data were structured and gathered into single comma-separated values (CSV) files. Each of these files was constructed to gather variables of the same nature (ex.: nutrients). In each file, a minimum number of variables (columns) was always included in order to make dataset merging easier and accurate (Table 4).

\section{Data description: an overview}

\subsection{Meteorological, navigational and ice coverage data}

Along the ship track, an Automated Voluntary Observing Ship (AVOS) system recorded all data related to navigation, including the position of the vessel and basic atmospheric meteorological data (including barometric pressure). A meteorological tower was also installed on the foredeck of the ship to measure additional variables (instantaneous wind speed and direction, air temperature and relative humidity, atmospheric partial pressure and vertical fluxes of CO2). Averaged wind speeds and directions over the entire Baffin Bay were retrieved from the Remote Sensing System website (http://www.remss.com/measurements/ccmp/) and were computed according to the Cross-Calibrated Multi-Platform (CCMP) wind vector analysis product (V2.0, Atlas et al., 2011) (see one example of a pattern calculated over the months of June and 
July in Fig. 5). A major change in wind patterns happened between Leg 1A (June, light 1-2 m s-1 southward winds) and 1B (July, 4-5 m s-1 northward winds), which impacts sea ice movements and potential changes in MIZ location. Figure 6 shows sea-ice cover over four periods covering the total sampling time of the cruise (https://nsidc.org/data/g02186). The north-south general orientation of the ice edge is visible, along with, over time, the westward progression of the MIZ.

Ice cover history was compiled and expressed as Open Water Days (OWD) before sampling day (Fig. 7), calculated from the difference (in day number) between the date of sampling and the date at which the sea-ice concentration reached 10 (panel A), 50 (panel B) and $80 \%$ (panel C) in the geographical location under study. Ice concentration data was obtained from the advanced microwave scanning radiometer (AMSR) -2 sea-ice concentration data on the $3.125 \mathrm{~km}$ grid (Spreen et al., 2008), downloaded from http://www.iup.uni-bremen.de:8084/amsr2data/asi_daygrid_swath/n3125/ (see Randelhoff et al., 2019, for details on the calculations). In Fig. 7, yellow and pale green colors on the Greenland side indicate a positive value between 20 and 40 OWD which reflects how long the open-water conditions had prevailed at those stations at the time of sampling. To the east, closer to the Canadian side, the colder colors and negative values indicate the presence of sea ice. Open water days is a useful metric/index and can be computed using different sea-ice cover (SIC) thresholds, depending on the goal. For example, in Randelhoff et al. (2019), the SIC value used for hydrological interpretation was $10 \%$ (as in Fig. 7 top panel). However, a biologist might want to consider a SIC of $80 \%$ (Fig.7 bottom panel) when looking for the onset of phytoplankton growth, as only $20 \%$ of open water surface already dramatically increases the available light.

\subsection{Physical data}

\subsubsection{Sea ice}

During sea-ice sampling operations, snow depth, ice thickness and freeboard were measured at each ice coring site. Over the cruise, ice thickness varied between 32 and $108 \mathrm{~cm}$, while freeboard varied between 10 and $-8 \mathrm{~cm}$. Several cores were retrieved at each site using a $9 \mathrm{~cm}$ diameter Mark II ice-corer (Kovacs Enterprises Inc., Roseburg, OR USA). Each ice core was sliced into $10 \mathrm{~cm}$ segments after temperature was measured. Salinity was assessed after thawing and filtration using a salinometer (Guildline Autosal 8400B, Guildline Instruments Ltd., Smith Falls, ON Canada). Snow density and granulometry were assessed opportunistically (Eicken et al., 2009).

\subsubsection{Water masses}

Hydrological conditions during the cruise were determined using several tools. A moving vessel profiler (MVP) was deployed, oscillating between 0 and $300 \mathrm{~m}$ depth while towed at an average speed of $12 \mathrm{knots}$, rendering a very high spatial resolution (Fig. 8 bottom row, one profile every $2 \mathrm{~km}$ ). Data obtained with the MVP matched the patterns observed from the rosette data acquired on sampling stations (Fig. 8 middle row). Profiles of conductivity, temperature and pressure were collected using a Sea-Bird SBE-911Plus CTD system rigged on the rosette. The data were post-processed according to the standard procedures recommended by the manufacturer and averaged over $0.2 \mathrm{~m}$ vertical bins (Guillot, 2016). While there was a sharp transition in SIC at the ice edge along transect 300, the change in SIC was less steep in the more extensive MIZ of transect 500 (top row in Fig. 8). Nonetheless, both transects show similar patterns, with $100 \%$ SIC, colder (below $-1{ }^{\circ} \mathrm{C}$ ) and fresher (salinity below $33.5 \mathrm{~g} \mathrm{~kg}-1$ ) waters close to the surface on the western side, and $0 \% \mathrm{SIC}$, saltier (above $33.6 \mathrm{~g} \mathrm{~kg}-1$ ) and warmer (above $0{ }^{\circ} \mathrm{C}$ ) waters within the first $50 \mathrm{~m}$ on the eastern side. These observations were consistent with the northward inflow of Atlanticorigin waters along the Greenland shelf break, and the southward outflow of Arctic/Pacific-origin waters along the Baffin Island shelf break.

Currents in the water column were measured using a hull-mounted $150 \mathrm{kHz}$ Acoustic doppler current profiler (ADCP, Teledyne RD Instruments Ocean Surveyor, California, USA), as well as two L-ADCP installed on the rosette structure (RDI, WHM300-1-UG304) in a Master/Slave configuration. Vertical profiles of water turbulence were measured at each FULL 
deployed from the zodiac. A detailed description of the hydrological structures in the studied area during the Green Edge cruise is presented in Randelhoff et al. (2019).

\subsection{Chemistry}

Partial pressure of $\mathrm{CO} 2$ (pCO2) was measured continuously (every two minutes) using a Li-7000 CO2 analyzer (LICOR, Lincoln NE, USA) coupled to a General Oceanics Underway System model 8050 (General Oceanics, Miami FL, USA) connected to the ship-track water monitoring system. At each FULL, BASIC and NUT station, discrete samples were collected using the Niskin bottles at 10 or more depths for seawater analysis (see Table 3 for the complete list). To complement the pCO2 data from the underway system and provide full profiles of the seawater $\mathrm{CO} 2$ system, total alkalinity and DIC concentrations were determined on discrete samples according to Dickson et al. (2007). Concentrations of the major macronutrients (nitrate, phosphate and orthosilicic acid) were determined with a segmented flow AutoAnalyzer model 3 (Seal Analytical, Germany) using standard colorimetric methods adapted from Grasshoff et al. (1999). Nitrate concentration in the water column was also determined during each CTD cast using an In situ ultraviolet spectrophotometer (ISUS, Satlantic Inc., Halifax NS Canada) profiler mounted on the rosette. Concentrations varied between 0 and non-limiting concentrations over the entire cruise, with concentrations gradually increasing from the surface to bottom. Surface waters showed higher concentrations of macronutrients in the western half of the transects than in the eastern half of the transects, indicating surface waters nutrients had been used by the developing PSB.

Organic elemental composition of total and dissolved matter (nitrogen, carbon and phosphorus) was measured on water samples taken from the Niskin bottles. Samples were immediately poisoned with sulfuric acid and brought back to the lab for analysis using wet oxidation, as described in Raimbault et al. (1999). Subtracting signals obtained for filtered samples (dissolved matter) from non-filtered samples (total matter) rendered calculated values for particulate organic matter. Particulate organic carbon and nitrogen were also analysed on filtered samples (Whatman ${ }^{\mathrm{TM}}$ glass fiber GF/F, GE Healthcare USA) using high-temperature oxidation combined with gas chromatography.

\subsection{Light Field and Bio-optics}

The characteristics of the light field (quantity and quality) passing through snow and sea ice into the water column were assessed, as light is the most important parameter triggering the PSB. From the top of the CCGS Amundsen wheelhouse, the total solar downwelling radiation was measured using a pyranometer ( 0.3 to $300 \mu \mathrm{m}$ wavelength) and a radiometer (visible range 300 to $750 \mathrm{~nm}$ ). Surface radiometry was performed using HyperSAS (Hyperspectral Surface Acquisition System, SeaBird Scientific USA) placed at the bow of the ship, including simultaneous measurements of hyperspectral above-water downward irradiance $(\operatorname{Ed}(0+, \lambda))$,sky and surface radiance $(\operatorname{Lsky}(0+, \lambda)$ or $\operatorname{Ltot}(0+, \lambda))$. Data were recorded at each FULL and BASIC station in open waters. Above-water hyperspectral remote sensing reflectance $(\operatorname{Rrs}(\lambda))$ was calculated from the radiometric quantities following the ocean optics protocols (Mueller et al., 2003; Mobley, 1999). In-water vertical profiles of downward irradiance $(\operatorname{Ed}(\mathrm{z}))$ and upward radiance $(\operatorname{Lu}(\mathrm{z}, \lambda)$ or irradiance $(\operatorname{Eu}(\mathrm{z}, \lambda))$ in the water column were measured using two different versions of the Compact Optical Profiling System (C-OPS, Biospherical Instruments Inc.) radiometer. In open waters, the free-fall version of the profiler was deployed from the ship (Antoine et al., 2013). The sea-ice version (ICE-Pro) was deployed during ice sampling through an auger hole carefully filled with fresh snow to avoid, as much as possible, disturbing the underwater light field. A reference sensor provided simultaneous measurements of downward irradiance in the air. All measurements were made at 19 different wavelengths between 320 and $875 \mathrm{~nm}$.

A profiling optical package was deployed at 28 stations to measure the inherent optical properties (IOPs) of seawater. The measured properties (and sensors) included: fluorescence of chlorophyll a and fluorescent dissolved organic matter (FDOM) (WetLabs, Eco Triplets), spectral total non-water absorption coefficients between 360 and $764 \mathrm{~nm}$ (Hobilabs, a-sphere), particle backscattering coefficient at six different wavelengths (Hobilabs, hydroscat-6, 394, 420, 470, 532, 620 and $700 \mathrm{~nm}$ ) 
together with CTD data (SeaBird sbe19+ attached to the package). In addition, discrete water samples were taken at each FULL and BASIC station to measure in the lab the CDOM absorption coefficient (aCDOM) between 200 and $722 \mathrm{~nm}$ using an Ultrapath (World Precision Instruments), and the phytoplankton and non-algal particle absorption coefficients between 200 and $860 \mathrm{~nm}$ determined from the "inside sphere" filter-pad technique (Rottgers and Gehnke, 2012; Stramski et al., 2015) using a spectrophotometer equipped with a 155-mm integrating sphere (Perkin Elmer Lambda 19). Note that aCDOM, phytoplankton and non-algal particle absorption coefficients were also measured on the bottom slice of thawed ice cores. The data revealed that the minimum light amount required for net phytoplankton growth $(0.415 \mathrm{~mol} \mathrm{~m}-2 \mathrm{~d}-1$; Letelier et al., 2004) can be reached deeper under the ice than expected (Randelhoff et al., 2019). Further details of the light field measurements can be found in Massicotte et al. (2019).

Three optical profilers were also attached to the rosette carousel and rendered 203 profiles of CDOM fluorescence (FluoCDOM Wetlabs USA) and chlorophyll concentration (estimated from in situ fluorescence, Seapoint fluorometer, USA), as well as 87 profiles of light transmittance (Wetlabs C-Star transmissometer, USA). Data is shown in Fig. 8 for transects 300 and 500. For both transects, the highest values of chlorophyll a concentration and of the attenuation coefficient (both parameters being strong proxies for phytoplankton biomass) were observed close to the surface in the MIZ, and deeper at around $50 \mathrm{~m}$ in icefree waters, showing a progression in the PSB development starting close to the surface along the ice edge and growing into a subsurface chlorophyll maximum (SCM) where surface waters were depleted in nutrients. Concentration of CDOM showed its lowest concentrations at the surface of open waters where SIC dropped below $50 \%$, and where the surface waters had been depleted of nutrients by phytoplankton growth.

\subsection{Biodiversity}

The Green Edge project also aimed to understand the related potential impacts of evolving environmental conditions on Arctic food-webs in the context of climate change. Hence, great care was taken to sample the entire size spectrum of particulate matter and living organisms (Fig. 9) from the tiniest viruses and bacteria to demersal fishes, seabirds and marine mammals. A wide variety of sampling techniques and analyses, from visual observation to highly automated underwater imaging systems, allowed us to ensure that almost all the levels of the trophic network were examined.

\subsubsection{Viruses and bacteria}

Abundance of viruses and bacteria was determined on fresh and preserved (glutaraldehyde $4 \%$ final concentration) water samples taken from the rosette at each FULL and BASIC station (10 depths) using two different flow cytometers. On board, fresh samples were counted using an Accuri ${ }^{\mathrm{TM}}$ C6 and preserved samples were counted back in the lab using a FACSCanto (both machines from Becton Dickinson Biosciences, San Jose CA, USA). Samples were processed according to Marie et al. (1999). Bacteria (and viruses) are ubiquitous in the oceans, and in Baffin Bay we measured bacterial abundances up to 2.9x106 cells ml-1.

For bacterial diversity analysis, water samples were filtered sequentially by means of a peristaltic pump onto $20 \mu \mathrm{m}$ and $3 \mu \mathrm{m}$ polycarbonate filters (Millipore) and then onto a $0.22 \mu \mathrm{m}$ filter cartridge (Sterivex-GV, Millipore). The filters and Sterivex were stored at $-80^{\circ} \mathrm{C}$ with RNAlater (Qiagen) until analyzed. The DNA/RNA co-extraction was carried out using the AllPrep DNA/RNA kit (Qiagen). The V4-V5 hypervariable region of the 16S rRNA gene of the DNA and cDNA samples was then amplified by PCR using primers 515F-Y and 926R covering a broad spectrum of diversity including Archaea and Bacteria (Parada et al., 2016). PCR, as well as sequencing settings and bioinformatic of sequence data, can be found in Dadaglio et al. (2018).

300 A comparison of the bacterial diversity as a function of geographic location and size fractions (free living bacteria, bacteria attached to particles smaller than $20 \mu \mathrm{m}$ and larger than $20 \mu \mathrm{m}$ ) was made at a relatively broad taxonomic level (Fig. 10). The samples from the different groups were mainly dominated by Bacteroidetes and Proteobacteria. In general, the proportion of 
Proteobacteria decreased from ice stations to open water stations featuring a more advanced stage of PSB, giving way to Bacteroidetes and more specifically Flavobacteriaceae.

\subsubsection{Phytoplankton community}

Flow cytometry was used (same protocols as for viruses and bacteria, Sect. 4.5.1) to count and differentiate the smallest cells (picophytoplankton, nanophytoplankton, cryptophytes and Synechococcus) according to their fluorescence and scattering properties at each FULL station. At the surface, picophytoplankton and nanophytoplankton cell concentrations could reach 60,000 (station G719) and 9000 (station G515) cell ml-1, respectively while cryptophytes were always below 360 cell ml-1.

310 Synechococcus cyanobacteria were never observed.

Some samples were used to start phytoplankton cultures, which were brought back to the Roscoff laboratory for purification using flow cytometry sorting, serial dilution and single-cell pipetting. Pure cultures were characterized by microscopy and $18 \mathrm{~S}$ rRNA gene sequencing. Most cultures isolated during the cruise belonged to diatoms, especially to the genera Attheya and Chaetoceros (Gérikas Ribeiro et al., 2020) All cultures were deposited to the Roscoff Culture Collection and available for distribution (http://www.roscoff-culture-collection.org/strains/shortlists/cruises/green-edge).

To study the phytoplankton community composition, an Imaging FlowCytobot (IFCB, McLane Research Laboratories Inc., East Falmouth MA, USA) was used during Leg 1b. The IFCB is best used for the study and identification of cells between 1 and $150 \mu \mathrm{m}$. Fresh samples $(5 \mathrm{~mL}$ ) taken from the rosette at each FULL station (all depths) and some BASIC and NUT stations ( 2 to 7 depths) were analyzed, as well as samples from the 2 bottom-most slices of ice cores once melted. The IFCB takes pictures at a resolution of around 3.4 pixels per $\mu \mathrm{m}$. Image descriptors/features were extracted with Matlab ${ }$, using scripts developed by Heidi Sosik (Sosik and Olson, 2007). Taxonomic determination was achieved using Ecotaxa (Picheral M, Colin $\mathrm{S}$, Irisson J-O. EcoTaxa, a tool for the taxonomic classification of images. http://ecotaxa.obs-vlfr.fr). Random forest algorithms were used for automatic classification. Reference set and validation of predictions were both done manually. Examples of specimens observed during the Green Edge campaigns can be found in Massicotte et al. (2019).

A total of 203 underwater vertical profiles were acquired using an underwater vision profiler (UVP, model 5-DEEP, Hydroptics France) installed on the frame of the rosette carousel. The UVP5 collects in-focus images in the small seawater volume lit by its light emitting diodes (LEDs), as it is lowered in the water column. An automated computer system (https://ecotaxa.obsvlfr.fr/) was used to sub-sample images of individual objects and sort them into the appropriate category (marine snow or various taxa of zooplankton). The UVP has been mainly developed to count and identify particles larger than $100 \mu \mathrm{m}$. Figure 11-left panels shows the average vertical profiles of particle concentration (ml-1) over the top $350 \mathrm{~m}$ of the water column, for open-water (top) and under-ice (bottom) stations. The number of particles close to the surface in open waters coincides with the larger phytoplankton biomass observed there compared with ice-covered stations (Fig. 13). It is consistent with lower primary and secondary production under sea ice. Deeper in the water column, around $300 \mathrm{~m}$, the large particle concentrations observed at open-water stations likely reflect resuspension of bottom sediments, because these observations were mostly made in the eastern part of Baffin Bay over the continental shelf, while under-ice stations were mostly located on the deeper canadian side of the Bay (see the bathymetry in Fig. 1).

Samples for taxonomic analyses of micro-algae by microscopy were taken at each FULL and BASIC station at ten sampling depths. Half a litre of seawater was preserved with Lugol and kept at $4{ }^{\circ} \mathrm{C}$ until it was analyzed in the laboratory. Visual observation and taxonomic determination were done using an inverted microscope (Eclipse TS100, Nikon Instrument Inc.)

340 according to the Ütermohl method (Ütermohl, 1958), using 25 or $50 \mathrm{ml}$ columns. Three transects of $26 \mathrm{~mm}$ at $400 \mathrm{x}$ were systematically observed for identification and counting of Bacillariophyceae, Dinophyceae, flagellates and ciliates. Larger phytoplankton cells and colonies were observed in all chambers at 100x. Diatoms (Bacillariophyceae) were found at every station, primarily at the surface of the water column, along with flagellates (both at the surface and at the SCM) (Fig. 12). The most striking feature was the dominating presence of a Phaeocystis sp. (Prymnesiophyceae, blue bars in Fig. 12) at the SCM, 
reaching 60 to $90 \%$ of the cell counts (and to a lesser extent at the surface) across a wide range of ice cover conditions (OWD values between -12 and 12 days).

Phytoplankton and ice-algae pigments were measured to derive indices of micro-algae biomass and taxonomic composition, and to get information on processes such as photoacclimation, senescence and grazing activities (Roy et al., 2011). Rosette water samples were filtered onto GF/F filters (Whatman ${ }^{\mathrm{TM}}$, GE Healthcare Life Sciences) and quickly frozen in liquid nitrogen. Back in the land-based laboratory, samples were thawed and extracted in 100\% methanol, separated and identified by HPLC, as described by Ras et al. (2008). Twenty-five individual pigments or groups of pigments were identified and quantified at each FULL and BASIC station (10 depths sampled each time). Figure 13 shows the distribution of total chlorophyll a and pheophorbide concentrations along transects 300 and 500. The high chlorophyll a concentrations close to the surface in the MIZ, and deepening towards open waters in the east, confirmed the evolution of the PSB from an under-ice bloom to an SCM. Note that highest concentrations of pheophorbide were systematically found underneath the accumulation of chlorophyll a, indicating the sinking of degrading phytoplanktonic material.

\subsubsection{Zooplankton and Fish}

Zooplankton represents the second level of the food chain. The UVP5 and the Imaging FlowCytobot (see previous sections) both rendered valuable information on small zooplankton specimens (below $150 \mu \mathrm{m}$ ). Figure 11-right panels shows copepod volumetric fraction ( $\mathrm{cm} 3 \mathrm{~m}-3)$ over the top $350 \mathrm{~m}$ of the water column, for open-water (top panel) and under-ice (bottom panel) stations. The total copepod volumetric fraction, calculated based on automatic identification made using the Ecotaxa web application (http://ecotaxa.obs-vlfr.fr), shows subsurface peaks around $20 \mathrm{~m}$ at both open-water and ice-covered stations. A secondary peak right at the surface is present at ice-covered stations, where a sub-population of copepods may stay close to the bottom of sea ice to feed on sympagic microalgae, small animals and related detritus.

For bigger specimens, a series of vertical nets and trawls were deployed at each FULL station (no trawling operations took place when sea ice was present). An assembly of 4 nets of 3 different mesh sizes (50, 200 and $500 \mu \mathrm{m})$ coupled with a Lightframe Onsight Key species Investigation (LOKI) system rendered high-resolution pictures of individuals sampled along the water columns together with actual specimens. The multi-net plankton sampler (Hydrobios) uses a different sampling strategy. Composed of 9 identical nets (200 $\mu \mathrm{m}$ mesh size), it is hauled vertically in the water column with the nets opening sequentially at different depths, each net collecting a slice of the water column displaying the vertical distribution of the species sampled. Figure 13C shows abundance (ind m-3) of zooplankton sampled using the vertical $200 \mu \mathrm{m}$ mesh net along transects 300 and 500. Copepods represent the main zooplankton class observed during the cruise and they were present at every sampling site. The particularly high abundance at station 507 (situated under the ice where a phytoplankton bloom had already disappeared) might be due to the relatively high abundance of Copepod Nauplii ( $25 \%$ of all Copepod individuals compared to the usual $4 \%$ at other stations).

Ichthyoplankton was sampled using a double square net towed obliquely from the side of the ship at a speed of ca. 2-3 knots to a maximum depth of $90 \mathrm{~m}$. A Star-Oddi ${ }^{\circledR}$ mini-CTD attached to the frame and flowmeters determined the real depth and volume of sampling. For fish sampling, an echo sounder (EK60, Simrad, Kongsberg Maritime, Norway) mounted on the hull was used to locate and determine the depth of fish aggregations along the ship track during the entire cruise. When pelagic juveniles and adult fish were present at the sampling stations, an Isaac-Kidd Midwater Trawl (IKMT, Filmar and QuébecOcéan, Québec, Canada) was towed for 20 minutes at a speed of 2 to 3 knots. When demersal fish were detected, a Benthic Beam Trawl (BBT, Filmar and Québec-Océan, Québec, Canada) was used to sample bigger specimens (between 10 and 32 mm mesh size) living on the bottom sediment.

Samples of zooplankton were all processed in the same way. Swimmers (fish larvae and juveniles) were sorted out, measured, identified and preserved in a mix of $95 \%$ ethanol and $1 \%$ glycerol (final concentrations) for later analysis, while zooplankton samples were preserved in $4 \%$ formaldehyde solution. Zooplankton abundance and diversity were determined using binoculars 
back at the laboratory. A few samples (hydrobios) were analyzed using the zooscan and the ecotaxa identification tools (https://ecotaxa.obs-vlfr.fr/prj/802). Fish from IKMT and BBT sampling were sorted, counted, identified and measured before preservation in the $-20^{\circ} \mathrm{C}$ freezer for further analysis. Acoustic data from the EK60 were analyzed in Echoview (see Geoffroy et al. (2016) for details)

\subsubsection{Benthos sampling}

Benthos sampling was performed to answer the following specific objectives to test if i) sea-ice cover is the primary environmental driver of contribution and geographic distribution of sympagic carbon on the seabed, (ii) sympagic carbon is the most important baseline food source supporting benthic consumers during spring in areas close to the MIZ, and iii) deep benthic food web dynamics and structural variability are directly linked with both depth and availability of food sources (Yunda-Guarin et al., 2020). The sampling was achieved using two different strategies; a total of 16 Agassiz trawling and 34 box coring operations (some down to more than $2000 \mathrm{~m}$ depth) were carried out during the cruise. The Agassiz trawl (KC Denmark a/s Research Equipment) is a medium-size dredge trawled behind the ship, allowing sampling of the macrofauna living on the sediment surface. Once brought back onboard, the content of the net was immediately rinsed with seawater, manually sorted and identified to the lowest taxonomic level as possible, when not possible samples were brought back in the laboratory to be identified under dissecting microscope. Figure 14 shows an example of the diversity of benthic organisms. More than 220 species of macrofauna were identified during the Green Edge cruise from more than 25 classes (Grant and Yunda-Guarin Unpublished data). A box corer was used to sample sediment from each FULL station. The sediment samples were then divided among the research teams for diverse analyses (see Table 3 for a complete list) including (but not limited to) identification of organisms living inside the sediment, incubations for respiration and nutrient utilization or chemical analysis.

\subsubsection{Birds and marine mammals}

During the entire cruise, a systematic bird and marine mammals survey was carried out from the ship's wheelhouse (see LeBlanc et al., 2019 for detailed methodology). A total of 20 different bird species and a total of 8 different mammal species were identified. Northern Fulmar, Thick-billed murre and Little auk were the most common bird species observed. Ringed seal, Hooded seal and Harp seal were the most common seals. The long-finned pilot whale was the most common whale species observed. A total of 10 polar bears were observed.

A total of 123 seabirds from 7 species were also collected from a zodiac deployed from the CCGS Amundsen in Greenland waters during Leg1 (10 June -8 July). This includes black-legged kittiwakes ( $\mathrm{n}=8)$, glaucous gulls ( $\mathrm{n}=6)$, great black-backed gull $(n=1)$, little auks $(n=19)$, northern fulmars $(n=42)$ and thick-billed murres $(n=36)$. Sampled birds were frozen at $-20^{\circ} \mathrm{C}$ until laboratory analyses. A first study aimed to investigate the co-distribution of seabirds and their fish prey along the MIZ (LeBlanc et al., 2019). To this end, stomach contents were examined for 74 birds (35 murres, 30 fulmars and 9 kittiwakes) under a dissecting microscope. Otoliths were retrieved and used to identify fish species, age and size. A second focus was recording of plastic in the stomachs. Plastic data are used in OSPAR monitoring and AMAP working groups on plastic pollution. A third study aimed to determine bird association to sea ice and ice-derived resources by the combination of different trophic markers (Cusset et al., unpublished). Hence, liver, muscle and blood (from the cardial clot) samples were collected from a total of 52 bird carcasses (27 murres, 14 auks, 3 kittiwakes and 8 fulmars), on which Highly Branched Isoprenoids (HBIs), carbon and nitrogen stable isotopes and fatty acids were measured. Finally, a fourth study is looking at stable isotope data together with $\mathrm{Hg}$ data for both muscle and liver. 


\section{Biological production and fluxes}

\subsection{Bacterial production, respiration and viability}

At each FULL station during the cruise, water samples were taken from 2-3 depths (surface, DCM and below DCM) to determine bacterial respiration. Oxygen concentration was determined using the Winkler method on 1- $\mu \mathrm{m}$ filtered samples before and after a 5 -day incubation in the dark at $1.5^{\circ} \mathrm{C}$. Bacterial respiration varied overall between 0 and $1.63 \mu \mathrm{mol} \mathrm{O} 21-1$ $\mathrm{d}-1$, with a mean value of $0.35 \pm 0.41 \mu \mathrm{mol} \mathrm{O} 21-1 \mathrm{~d}-1$. For bacterial production determination, water was collected at each FULL station from 8-10 depths. Bacterial production was measured by [H3]-Leucine incorporation (Kirchman et al., 1985) modified for microcentrifugation (Smith and Azam, 1992). Overall values varied between 0 and $1.51 \mu \mathrm{gC} 1-1 \mathrm{~d}-1$ around a mean value of $0.17 \pm 0.25 \mu \mathrm{gC} 1-1 \mathrm{~d}-1$. The use of the propidium monoazide (PMA) method allowed to show a high bacterial mortality in sea ice (up to 90\%) and in SPM material (up to 68\%) collected in shallower waters at St 409 and St 418 (Burot et al., 2021).

\subsection{Primary production and micronutrient cycling}

To determine the fate of the phytoplankton spring bloom, one must first determine primary production. In situ simulated incubations were carried out at each FULL station on water sampled from the rosette at 8 to 10 depths determined as chosen percentages of surface photosynthetic available radiation (PAR, namely 100, 50, 25, 10, 6, 2.9, 1.2, 0.6 amd 0.1\%). The melted bottom-most slices of ice cores were also incubated, when available. After spiking the water with a mix of $13 \mathrm{C} / 15 \mathrm{~N}$ tracers, samples were incubated on deck at simulated light levels identical to the sampling light levels. The dissolved and particulate matter resulting from these incubations were analyzed by mass-spectrometry resulting in detailed nitrogen assimilation and regeneration values (see Table 3 for a complete list of parameters), as well as phytoplankton primary production (PP). Primary production varied between 0 and $88.13 \pm 3.0 \mu \mathrm{gC} 1-1$ day-1 over the entire cruise.

Photosynthetic parameters also allow calculation of primary production and provide insight into the efficiency and characteristics of photosynthesis of a given sample. Onboard, photosynthetic parameters were determined by the $\mathrm{P}$ vs $\mathrm{E}$ curves method using NaH14CO3- spiked incubations of water samples (Lewis and Smith, 1983). Changes in the saturation parameter Ek ( $\mu$ mol Quanta m-2 s-1) in the surface waters of the transect show clear variations in light level acclimation, increasing from lower values around $39 \mu \mathrm{mol}$ Quanta m-2s-1 at the western under-ice stations to $217 \mu \mathrm{mol}$ Quanta $\mathrm{m}-2 \mathrm{~s}-1$ at the eastern openwater stations (transect 700 values given as an example). Great emphasis was placed on the contribution of diatoms to primary production, as diatoms are the main phytoplankton group present during the PSB. Experiments on silica precipitation and dissolution were performed throughout the cruise to locate the actively growing diatoms. These experiments confirmed the occurrence of active silicification beneath the sea ice, where both centric and pennate diatoms were observed (see details in Lafond et al. (2019)).

\subsection{Fate of the phytoplankton spring bloom}

Some organic matter produced by the PSB was exported down the water column, as algal cells aggregated and sank, or were grazed upon by vertically migrating zooplankton. One ambitious experiment was conducted during the cruise to monitor the export of the PSB at a high temporal resolution. A sequential sediment trap (Technicap PPS4 France; 12 sampling cups) was anchored to an ice floe and deployed $25 \mathrm{~m}$ under the ice from June 15th to July 9th, 2016. Sediment trap collection cups were filled with filtered seawater adjusted to a salinity of 38 with $\mathrm{NaCl}$ and a formalin concentration of $4 \%$ to preserve samples during deployment and after recovery. The carousel holding the sampling cups was programmed to rotate every 2 days. The sediment trap was deployed in the marginal ice zone along transect 200 (Fig. 1), eventually drifted south with the ice, and was recovered on the way back to Iqaluit. The sediment trap was no longer anchored to its floe at recovery, but sea ice was still present in the region. Taxonomic identification of the algal cells collected showed a constant export of diatoms $(\sim 50$ million 
cells $\mathrm{m}-2 \mathrm{~d}-1$ ) from June 15 th to early July, when a 6-fold increase in diatom fluxes was observed from July 5 th to July 7 th ( $\sim 300$ million cells m-2 d-1) along with a peak in chlorophyll a fluxes. More than half of the cells exported during the peak in algal fluxes were identified as the ice-associated pennate diatom Navicula spp.. Fluxes of the ice-obligate pennate diatom Nitzschia frigida, among the first species to be consistently exported from the melting sea ice in the Arctic Ocean (Lalande et al., 2019; Dezutter et al., 2021; Nadaï et al., 2021), peaked from June 23rd to June 25th, probably indicating the onset of sea ice melt. Fluxes of copepod fecal pellets collected in the sediment trap were higher prior to June 27 th, suggesting under-ice grazing of ice algae until the ice melted.

\subsection{Benthic processes}

Taken from the box corer, portions of the sediment were incubated at in situ simulated conditions of temperature and light in order to assess the consumption of oxygen and nutrients by endofauna. Oxygen use in the sediment cores allowed calculation of the benthic carbon demand ( $\mathrm{mgC} \mathrm{m}-2 \mathrm{~d}-1)$ which was found to be especially high at stations in open waters where the PSB had already reached senescence and sinking organic matter had reached the bottom.

\subsection{Other data}

The exhaustive list of parameters measured during the cruise is presented in Table 3 along with principal investigator (PI) contact information.

\section{Data availability}

Raw data (and associated meta-data) are available on the LEFE-CYBER website at: http://www.obsvlfr.fr/proof/php/GREENEDGE/x_datalist_1.php?xxop=greenedge\&xxcamp=amundsen. The formatted data are available on SEANOE (SEA scieNtific Open data Edition) under the CC-BY license (https://www.seanoe.org/data/00487/59892/, Massicotte et al. (2019)). Detailed metadata associated with each data file contain the principal investigator's contact information. For specific questions, the PI associated with the data should be contacted directly. Dissolved inorganic carbon (DIC), alkalinity, and O-18 data are also archived with the Ocean Carbon Data System (OCADS) https://doi.org/10.25921/719e-qr37. Navigation, ADCP, MVP and CTD data are also available on the Polar Data Catalog (https://www.polardata.ca/).

\section{Lessons learned}

490 As for any scientific cruise, a large amount of data was acquired by many people. Even though guidelines had been suggested ahead of time for data formatting, merging and storage, a tremendous amount of effort was necessary to collect, assemble and standardize the data. It is important that a clear and streamlined data management plan be established ahead of time in order to avoid errors or loss of data in the merging process. For oceanographic CTD-rosette sampling-based cruises, depth of sampling necessitates special attention, as it is crucial to use Niskin bottle number instead of nominal depth in order to correctly merge the data. Furthermore, we cannot emphasize enough that data management specialists must be involved from the beginning of such large-scale projects, to ensure that data is properly documented, in order to render the best quality data set possible and avoid loss of both valuable time and data.

\section{Conclusion}

The Green Edge cruise was of typical oceanographic design. In terms of goal achievement, the cruise was extremely successful and generated an impressive data set over a diverse set of disciplines, providing a global picture of the explored environment 
and of all the processes fuelling the Arctic food-web. Figure 15 represents all interactions existing and/or measured during the cruise between compartments of the various trophic levels. The generated data set contains a much larger number of parameters than those presented in this paper. All data can be obtained from the data repository and provide an excellent opportunity for re-use and comparison with other Arctic data sets. A special issue of the Elementa journal entitled Green Edge -The phytoplankton spring bloom in the Arctic Ocean: past, present and future response to climate variations, and impact on carbon fluxes and the marine food web contains a collection of research papers referring to this cruise.

\section{Authors contribution}

MB designed the Green Edge project, including the scientific objectives and sampling strategy. MB, KL, FB, TL, PG, GJ, TB, MP, CM, KC, DM, MT, GD, GF, LD, JD, CL, ML, GN, NM, MC, MP, K-ML, HJ-W, ER, AV, LBdF, DD, NG, HC, AS, BQ, SH, GB, SEG, CG, P-LG, JET, EB, CS, MGT, JR, AB, RA, CB, BM, JL, EL, PB and PC were onboard the ship and took part in sampling and on-board analysis. FB, PG, GJ, TB, MP, CM, KC, DM, MT, GD, LD, GF, LD, JD, CL, LM, GN, NM, NP, K-ML, HJ-W, ER, AV, LBdF, DD, NG, HC, AS, BG, SH, GB, GC, P-LG, M-NH, CS, MGT, JR, AB, RA, CB, BM, JL, EL, BS-B, PC, PA, LA, SB, DC, VC-B, FC, MD, CD, BE, IE, JF, LF, MG, CGR, CG, PG, CG, SH, RH, FJ, AL, PL, FLG, KL, JL, AL, ML, ALdS, GM, AM, LAM, P-IM, AM, AM, CP, MP, PR, J-FR, RS, JT, A-PT, DV and CN took part in processing and analyzing of the samples and in generating data. M-PA, and PM cleaned, merged and assembled the dataset. CS maintains the Les Enveloppes Fluides et l'Environnement-Cycles Biogéochimiques Environnement et Ressources (LEFE-CYBER) repository it is stored in. NS, SM, JS, LRL, TP and PB oversaw communication and outreach. MHF, JF, JL and FB oversaw logistics.

\section{Acknowledgments}

The Green Edge project was funded by the following French and Canadian programs and agencies: Agence nationale de recherche (ANR) (Contract \#111112), ArcticNet, Canada Excellence Research Chair (CERC) on Remote sensing of Canada's new Arctic frontier, le Centre national d'études spatiales (CNES, project \#131425), French Arctic Initiative, Fondation Total, Canadian space agency, LEFE and Institut Paul-Emile Victor (IPEV, project \#1164). This project was conducted using the Canadian research icebreaker CCGS Amundsen with the support of the Amundsen Science program funded by the Canada Foundation for Innovation (CFI) Major Science Initiatives (MSI) Fund, Fisheries and Ocean Canada funded the DIC, alkalinity and O-18 sample analysis. We wish to thank the officers and crew of the CCGS Amundsen. The project was conducted under the scientific coordination of the CERC on Remote sensing of Canada's new Arctic frontier and the Centre national de la recherche scientifique CNRS/Université Laval Takuvik Joint International Laboratory (IRL3376). The field campaign was successful thanks to the contributions of G. Bécu, J. Lagunas, D. Christiansen-Stowe, J. Sansoulet, E. Rehm, M. Benoît-Gagné, M.-H. Forget and F. Bruyant from Takuvik laboratory and J. Bourdon, C. Marec and M. Picheral from CNRS. We also thank Québec-Océan and the Polar Continental Shelf Program for their in-kind contribution in terms of polar logistics and scientific equipment. We thank Marie-Pier Amyot for data cleaning and Étienne Ouellet for IT support and data infrastructure management.

The authors declare that they have no conflict of interest.

\section{References}

Ackley, H. Eicken, F., Gradinger, R., Salganek, M., Shirasawa, K., Perovich, D. and Lepparanta, M.: Field Techniques for Sea Ice Research, in Arctic, Antarctic, and Alpine Research, vol. 42, pp. 503-504., 2010. 
André, X., Le Traon, P.-Y., Le Reste, S., Dutreuil, V., Leymarie, E., Malardé, D., Marec, C., Sagot, J., Amice, M., Babin, M., Claustre, H., David, A., D’Ortenzio, F., Kolodziejczyk, N., Lagunas, J. L., Le Menn, M., Moreau, B., Nogré, D., Penkerc'h, C., Poteau, A., Renaut, C., Schaeffer, C., Taillandier, V. and Thierry, V.: Preparing the New Phase of Argo: Technological Developments on Profiling Floats in the NAOS Project, Front. Mar. Sci., 7(November), 1-22, doi:10.3389/fmars.2020.577446, 2020.

Ardyna, M., Babin, M., Gosselin, M., Devred, E., Bélanger, S., Matsuoka, A. and Tremblay, J. E.: Parameterization of vertical chlorophyll a in the Arctic Ocean: Impact of the subsurface chlorophyll maximum on regional, seasonal, and annual primary production estimates, Biogeosciences, 10(6), 4383-4404, doi:10.5194/bg-10-4383-2013, 2013.

Arrigo, K. R., Perovich, D. K., Pickart, R. S., Brown, Z. W., van Dijken, G. L., Lowry, K. E., Mills, M. M., Palmer, M. A., Balch, W. M., Bates, N. R., Benitez-Nelson, C. R., Brownlee, E., Frey, K. E., Laney, S. R., Mathis, J., Matsuoka, A., Greg Mitchell, B., Moore, G. W. K., Reynolds, R. A., Sosik, H. M. and Swift, J. H.: Phytoplankton blooms beneath the sea ice in the Chukchi sea, Deep. Res. Part II Top. Stud. Oceanogr., 105, 1-16, doi:10.1016/j.dsr2.2014.03.018, 2014.

Assmy, P., Fernández-Méndez, M., Duarte, P., Meyer, A., Randelhoff, A., Mundy, C. J., Olsen, L. M., Kauko, H. M., Bailey, A., Chierici, M., Cohen, L., Doulgeris, A. P., Ehn, J. K., Fransson, A., Gerland, S., Hop, H., Hudson, S. R., Hughes, N., Itkin, P., Johnsen, G., King, J. A., Koch, B. P., Koenig, Z., Kwasniewski, S., Laney, S. R., Nicolaus, M., Pavlov, A. K., Polashenski, C. M., Provost, C., Rösel, A., Sandbu, M., Spreen, G., Smedsrud, L. H., Sundfjord, A., Taskjelle, T., Tatarek, A., Wiktor, J., Wagner, P. M., Wold, A., Steen, H. and Granskog, M. A.: Leads in Arctic pack ice enable early phytoplankton blooms below snow-covered sea ice OPEN, Nat. Publ. Gr., doi:10.1038/srep40850, 2016.

Atlas, R., Hoffman, R. N., Ardizzone, J., Leidner, S. M., Jusem, J. C., Smith, D. K. and Gombos, D.: A cross-calibrated, multiplatform ocean surface wind velocity product for meteorological and oceanographic applications, Bull. Am. Meteorol. Soc., 92(2), 157-174, doi:10.1175/2010BAMS2946.1, 2011.

Burot, C., Amiraux, R., Bonin, P., Guasco, S., Babin, M., Joux, F., Marie, D., Vilgrain, L., Heipieper, H. J. and Rontani, J. F.: Viability and stress state of bacteria associated with primary production or zooplankton-derived suspended particulate matter in summer along a transect in Baffin Bay (Arctic Ocean), Sci. Total Environ., 770, 145252, doi:10.1016/j.scitotenv.2021.145252, 2021.

Collins, M., R. Knutti, J. Arblaster, J.-L. Dufresne, T. Fichefet, P. Friedlingstein, X. Gao, W.J. Gutowski, T. Johns, G. Krinner, M. Shongwe, C. Tebaldi, A.J. Weaver and M. Wehner: Long-term Climate Change: Projections, Commitments and Irreversibility. In: Climate Change 2013: The Physical Science Basis. Contribution of Working Group I to the Fifth Assessment Report of the Intergovernmental Panel on Climate Change [Stocker, T.F., D. Qin, G.-K. Plattner, M. Tignor, S.K. Allen, J. Boschung, A. Nauels, Y. Xia, V. Bex and P.M. Midgley (eds.)]. Cambridge University Press, Cambridge, United Kingdom and New York, NY, USA, 2013.

Dezutter, T., Lalande, C., Darnis, G. and Fortier, L.: Seasonal and interannual variability of the Queen Maud Gulf ecosystem derived from sediment trap measurements, Limnol. Ocean., 66, 411-426, doi:10.1002/lno.11628, 2021.

Dickson, A. G., Sabine, C. L. and Christian, J. R.: Guide to Best Practices for Ocean CO2 measurements. PICES Special Publication., 2007.

Geoffroy, M., Majewski, • Andrew, Leblanc, • Mathieu, Gauthier, S., Walkusz, W., Reist, J. D. and Fortier, • Louis: Vertical segregation of age- 0 and age- $1+$ polar cod (Boreogadus saida) over the annual cycle in the Canadian Beaufort Sea, Polar Biol., 39, doi:10.1007/s00300-015-1811-z, n.d. Guillot, P.. CTD Data Collected by the CCGS Amundsen in the Canadian Arctic, 2016. Grasshoff, K., Kremling, K. and Ehrhardt, M.: Methods of Seawater Analysis., 1999.

Kirchman, D., K'nees, E. and Hodson, R.: Leucine incorporation and its potential as a measure of protein synthesis by bacteria in natural aquatic systems, Appl. Environ. Microbiol., 49(3), 599-607, doi:10.1128/aem.49.3.599-607.1985, 1985. 
Lafond, A., Leblanc, K., Quéguiner, B., Moriceau, B., Leynaert, A., Cornet, V., Legras, J., Ras, J., Parenteau, M., Garcia, N., Babin, M. and Tremblay, J. É.: Late spring bloom development of pelagic diatoms in Baffin Bay, Elementa, 7(1), doi:10.1525/elementa.382, 2019.

Lalande, C., Nöthig, E.-M. and Fortier, L.: Algal Export in the Arctic Ocean in Times of Global Warming, , doi:10.1029/2019GL083167, 2019.

Laney, S. R. and Sosik, H. M.: Phytoplankton assemblage structure in and around a massive under-ice bloom in the Chukchi Sea, Deep Sea Res. Part II Top. Stud. Oceanogr., 105, 30-41, doi:10.1016/J.DSR2.2014.03.012, 2014.

LeBlanc, M., Gauthier, S., Garbus, S. E., Mosbech, A. and Fortier, L.: The co-distribution of Arctic cod and its seabird predators across the marginal ice zone in Baffin Bay, Elementa, 7(1), 1-18, doi:10.1525/elementa.339, 2019.

Letelier, R. M., Karl, D. M., Abbott, M. R. and Bidigare, R. R.: Light driven seasonal patterns of chlorophyll and nitrate in the lower euphotic zone of the North Pacific Subtropical Gyre, Limnol. Oceanogr., 49(2), 508-519, doi:https://doi.org/10.4319/1o.2004.49.2.0508, 2004.

Le Traon, P. Y., D’Ortenzio, F., Babin, M., Leymarie, E., Marec, C., Pouliquen, S., Thierry, V., Cabanes, C., Claustre, H., Desbruyères, D., Lacour, L., Lagunas, J. L., Maze, G., Mercier, H., Penkerc'h, C., Poffa, N., Poteau, A., Prieur, L., Racapé, V., Randelhoff, A., Rehm, E., Schmechtig, C. M., Taillandier, V., Wagener, T. and Xing, X.: Preparing the New Phase of Argo: Scientific Achievements of the NAOS Project, Front. Mar. Sci., 7(October), doi:10.3389/fmars.2020.577408, 2020.

Leu, E., Mundy, C. J., Assmy, P., Campbell, K., Gabrielsen, T. M., Gosselin, M., Juul-Pedersen, T. and Gradinger, R.: Arctic spring awakening - Steering principles behind the phenology of vernal ice algal blooms, Prog. Oceanogr., 139, 151-170, doi:10.1016/j.pocean.2015.07.012, 2015.

Lewis, M. R. and Smith, J. C.: A small volume, short-incubation-time method for measurements of photosynthesis as a function of incident irradiance, Mar. Ecol. Prog. Ser., 13, 99-102, 1983.

Lowry, K. E., van Dijken, G. L. and Arrigo, K. R.: Evidence of under-ice phytoplankton blooms in the Chukchi Sea from 1998 to 2012, Deep. Res. Part II Top. Stud. Oceanogr., 105, 105-117, doi:10.1016/j.dsr2.2014.03.013, 2014.

Marie, D., Partensky, F., Vaulot, D. and Brussaard, C.: Enumeration of Phytoplankton, Bacteria, and Viruses in Marine Samples, edited by I. John Wiley \& Sons, Curr. Protoc. Cytom., 10(1), 11.11.1-11.11.15, doi:10.1002/0471142956.cy1111s10, 1999.

Massicotte, P., Amiraux, R., Amyot, M.-P., Archambault, P., Ardyna, M., Arnaud, L., Artigue, L., Aubry, C., Ayotte, P., Bécu, G., Bélanger, S., Benner, R., Bittig, H. C., Bricaud, A., Brossier, E., Bruyant, F., Chauvaud, L., Christiansen-Stowe, D., Claustre, H., Cornet-Barthaux, V., Coupel, P., Cox, C., Delaforge, A., Dezutter, T., Dimier, C., Domine, F., Dufour, F., Dufresne, C., Dumont, D., Ehn, J., Else, B., Ferland, J., Forget, M.-H., Fortier, L., Galí, M., Galindo, V., Gallinari, M., Garcia, N., Gérikas Ribeiro, C., Gourdal, M., Gourvil, P., Goyens, C., Grondin, P.-L., Guillot, P., Guilmette, C., Houssais, M.-N., Joux, F., Lacour, L., Lacour, T., Lafond, A., Lagunas, J., Lalande, C., Laliberté, J., Lambert-Girard, S., Larivière, J., Lavaud, J., Lebaron, A., Leblanc, K., Le Gall, F., Legras, J., Lemire, M., Levasseur, M., Leymarie, E., Leynaert, A., Lopes Dos Santos, A., Lourenço, A., Mah, D., Marec, C., Marie, D., Martin, N., Marty, C., Marty, S., Massé, G., Matsuoka, A., Matthes, L., Moriceau, B., Muller, P.-E., Mundy, C.-J., Neukermans, G., Oziel, L., Panagiotopoulos, C., Pangrazi, J.-J., Picard, G., Picheral, M., Pinczon Du Sel, F., Pogorzelec, N., Probert, I., Quéguiner, B., Raimbault, P., Ras, J., Rehm, E., Reimer, E., Rontani, J.F., Rysgaard, S., Saint-Béat, B., Sampei, M., Sansoulet, J., Schmechtig, C., Schmidt, S., et al.: Green edge ice camp campaigns: Understanding the processes controlling the under-ice arctic phytoplankton spring bloom, Earth Syst. Sci. Data, 12(1), doi:10.5194/essd-12-151-2020, 2020.

Meredith, M., M. Sommerkorn, S. Cassotta, C. Derksen, A. Ekaykin, A. Hollowed, G. Kofinas, A. Mackintosh, J. MelbourneThomas, M.M.C. Muelbert, G. Ottersen, H. Pritchard, and E.A.G. Schuur, Polar Regions. In: IPCC Special Report on the Ocean and Cryosphere in a Changing Climate [H.-O. Pörtner, D.C. Roberts, V. Masson-Delmotte, P. Zhai, M. Tignor, E. Poloczanska, K. Mintenbeck, A. Alegría, M. Nicolai, A. Okem, J. Petzold, B. Rama, N.M. Weyer (eds.)], 2019. 
Miller, L.A., M. Davelaar, D. Caleb, A. Mucci, T.M. Burgers, M. Ahmed, and V. Irish, Dissolved inorganic carbon (DIC), total alkalinity, stable oxygen isotope (O-18), temperature, salinity, dissolved oxygen and other parameters measured from discrete samples and profile observations during the Canadian Coast Guard Ship Amundsen ArcticNet cruise (EXPOCODE 18DL20160603, Leg 1 and Leg 2) in the Eastern Canadian Arctic, Baffin Bay, Nares Strait, Lancaster Sound, Barrow Strait and Coronation Gulf from 2016-06-03 to 2016-08-23 (NCEI Accession 0217304). NOAA National Centers for Environmental Information. Dataset. https://doi.org/10.25921/719e-qr37, 2020.

630 Mundy, C. J., Gosselin, M., Ehn, J., Gratton, Y., Rossnagel, A., Barber, D. G., Martin, J., Tremblay, J. É., Palmer, M., Arrigo, K. R., Darnis, G., Fortier, L., Else, B. and Papakyriakou, T.: Contribution of under-ice primary production to an ice-edge upwelling phytoplankton bloom in the Canadian Beaufort Sea, Geophys. Res. Lett., 36(17), 1-5, doi:10.1029/2009GL038837, 2009.

Nadaï, G., Nöthig, E. M., Fortier, L. and Lalande, C.: Early snowmelt and sea ice breakup enhance algal export in the Beaufort Sea, Prog. Oceanogr., 190, 102479, doi:10.1016/J.POCEAN.2020.102479, 2021.

Olson, R. and Sosik, H. M.: A submersible imaging-in-flow instrument to analyze nano- and microplankton: Imaging FlowCytobot., Limnol. Oceanogr. Methods, 5, 195-203, 2007.

Oziel, L., Massicotte, P., Randelhoff, A., Ferland, J., Vladoiu, A., Lacour, L., Galindo, V., Lambert-Girard, S., Dumont, D., Cuypers, Y., Bouruet-Aubertot, P., Mundy, C.-J., Ehn, J., Bécu, G., Marec, C., Forget, M.-H., Garcia, N., Coupel, P., Raimbault, P., Houssais, M.-N. and Babin, M.: Environmental factors influencing the seasonal dynamics of spring algal blooms in and beneath sea ice in western Baffin Bay, Elem. Sci. Anthr., 7, doi:10.1525/elementa.372, 2019.

Perrette, M., Yool, A., Quartly, G. D. and Popova, E. E.: Near-ubiquity of ice-edge blooms in the Arctic, Biogeosciences, 8(2), 515-524, doi:10.5194/bg-8-515-2011, 2011.

Picheral M, Colin S, Irisson J.-O., EcoTaxa, a tool for the taxonomic classification of images. http://ecotaxa.obs-vlfr.fr, 2017.

Raimbault, P., Pouvesle, W., Diaz, F., Garcia, N. and Sempéré, R.: Wet-oxidation and automated colorimetry for simultaneous determination of organic carbon, nitrogen and phosphorus dissolved in seawater, Mar. Chem., 66(3-4), 161-169, doi:10.1016/S0304-4203(99)00038-9, 1999.

Randelhoff, A., Oziel, L., Massicotte, P., Bécu, G., Galí, M., Lacour, L., Dumont, D., Vladoiu, A., Marec, C., Bruyant, F., Houssais, M. N., Tremblay, J. É., Deslongchamps, G. and Babin, M.: The evolution of light and vertical mixing across a phytoplankton ice-edge bloom, Elementa, 7(1), doi:10.1525/elementa.357, 2019.

Ras, J., Claustre, H. and Uitz, J.: Spatial variability of phytoplankton pigment distributions in the Subtropical South Pacific Ocean: Comparison between in situ and predicted data, Biogeosciences, 5(2), 353-369, doi:10.5194/bg-5-353-2008, 2008.

Ribeiro, C. G., dos Santos, A. L., Gourvil, P., Le Gall, F., Marie, D., Tragin, M., Probert, I. and Vaulot, D.: Culturable diversity of Arctic phytoplankton during pack ice melting, Elementa, 8(1), doi:10.1525/elementa.401, 2020.

Röttgers, R. and Gehnke, S.: Measurement of light absorption by aquatic particles: Improvement of the quantitative filter technique by use of an integrating sphere approach, Appl. Opt., 51(9), 1336-1351, doi:10.1364/AO.51.001336, 2012.

Roy, S., Llewellyn, C., Egeland, E. and Johnsen, G.: Phytoplankton pigments : characterization, chemotaxonomy, and applications in oceanography, Cambridge University Press, Cambridge, U.K. :, 2011.

Simon, M. and Azam, F.: Protein content and protein synthesis rates of planktonic marine bacteria, Mar. Ecol. Prog. Ser., 51, 201-213, doi:10.3354/meps051201, 1989.

Smith, D.C., and Azam, F., A simple, economical method for measuring bacterial protein synthesis rates in seawater using 3H-leucine. Mar. microb. food webs 6: 102-114, 1992.

Sosik, H. M. and Olson, R. J.: Automated taxonomic classification of phytoplankton sampled with imaging in-flow cytometry, Limnol. Oceanogr. Methods, 5, 204-216 [online] Available from: http://www.whoi.edu/mvco, 2007.

Spreen, G., Kaleschke, L. and Heygster, G.: Sea ice remote sensing using AMSR\&hyphen;E 89\&hyphen;GHz channels, J. Geophys. Res, 113, 2-03, doi:10.1029/2005JC003384, 2008. 
Stramski, D., Reynolds, R. A., Kaczmarek, S., Uitz, J. and Zheng, G.: Correction of pathlength amplification in the filter-pad technique for measurements of particulate absorption coefficient in the visible spectral region, Appl. Opt., 54(22), 6763, doi:10.1364/ao.54.006763, 2015.

670 U.S. National Ice Center and National Snow and Ice Data Center. Compiled by F. Fetterer, M. Savoie, S. Helfrich, and P. Clemente-Colón.: updated daily. Multisensor Analyzed Sea Ice Extent - Northern Hemisphere (MASIE-NH), Version 1. Boulder, Colorado USA. NSIDC: National Snow and Ice Data Center. doi: https://doi.org/10.7265/N5GT5K3K, 2010.

Utermöhl, H.: Zur Vervollkommnung der Quantitativen Phytoplankton-Methodik Mitt. Int. Ver. Theor. Angew. Limnol. 9: 1$38,1958$.

Wassmann, P. and Reigstad, M.: Future Arctic Ocean Seasonal Ice Zones and Implications for Pelagic-Benthic Coupling, Oceanography, 24(3), 220-23, 2011.

Yunda-Guarin, G., Brown, T. A., Michel, L. N., Saint-Béat, B., Amiraux, R., Nozais, C. and Archambault, P.: Reliance of deep-sea benthic macrofauna on ice-derived organic matter highlighted by multiple trophic markers during spring in Baffin Bay, Canadian Arctic, Elem. Sci. Anthr., 8(1), doi:10.1525/ELEMENTA.2020.047/114544, 2020. 
https://doi.org/10.5194/essd-2022-41

Preprint. Discussion started: 21 February 2022

(c) Author(s) 2022. CC BY 4.0 License.

\section{FIGURES}
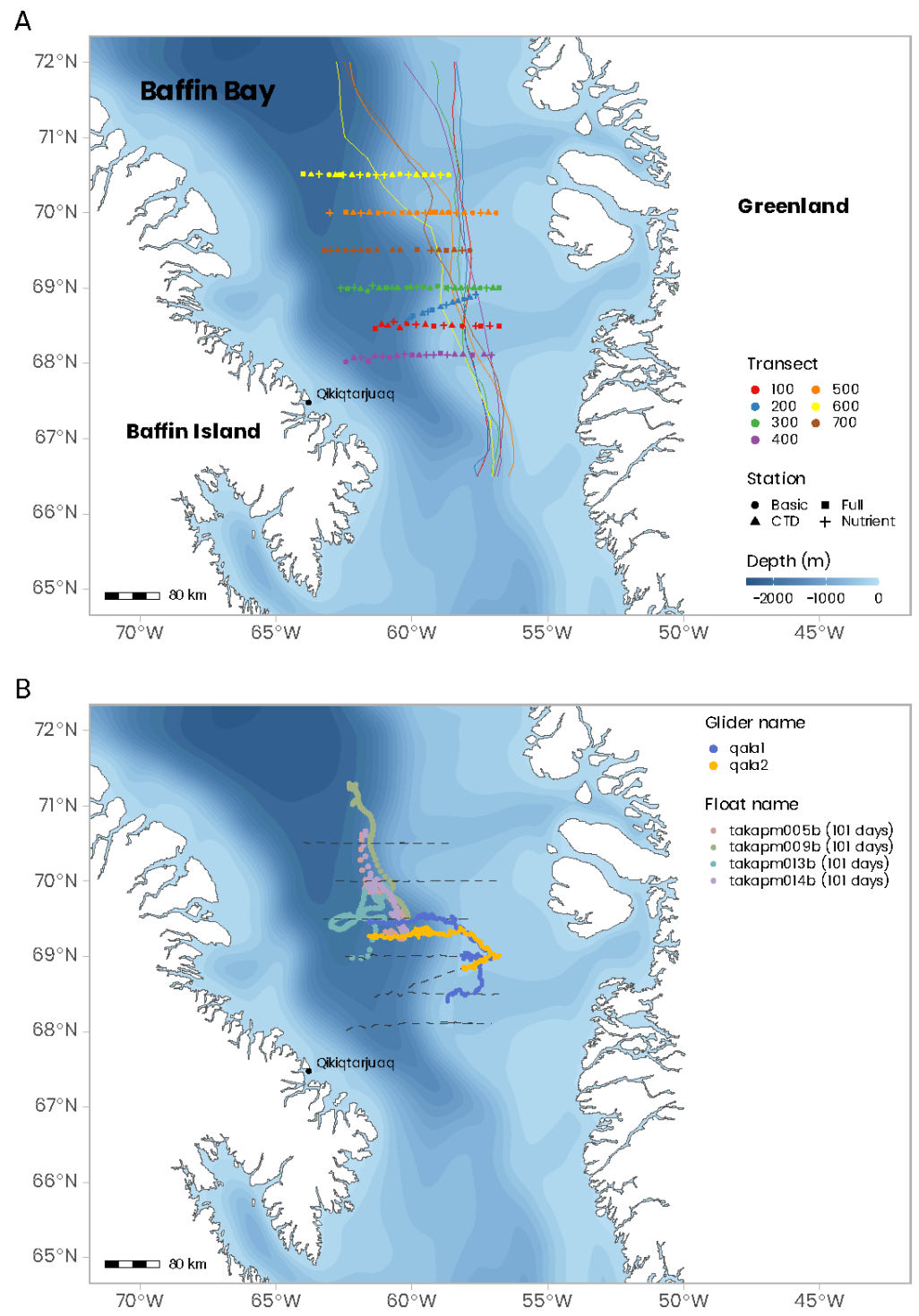

Figure 1: Cruise maps showing (a) the seven transects and all stations with shape distinction between station type (FULL, BASIC, NUT and CTD, see Table 1 for description). Colored lines indicate the position of the eastern ice edge on each transect at date of sampling (sea ice concentration at 80\%). Starting date of each transect sampling is as follow: June 9th (100), June 14th (200), June 17th (300), June 24th (400), June 29th (500), July 3rd (600) and July 7th (700). (b) Tracks of the 4 BioArgo floats deployed during the Green Edge Cruise over their lifetime, and the journey of the two Slocum gliders (blue and orange). The dashed line represents the ship track along the seven transects. 
https://doi.org/10.5194/essd-2022-41

Preprint. Discussion started: 21 February 2022

(c) Author(s) 2022. CC BY 4.0 License.

(c) (i)

690

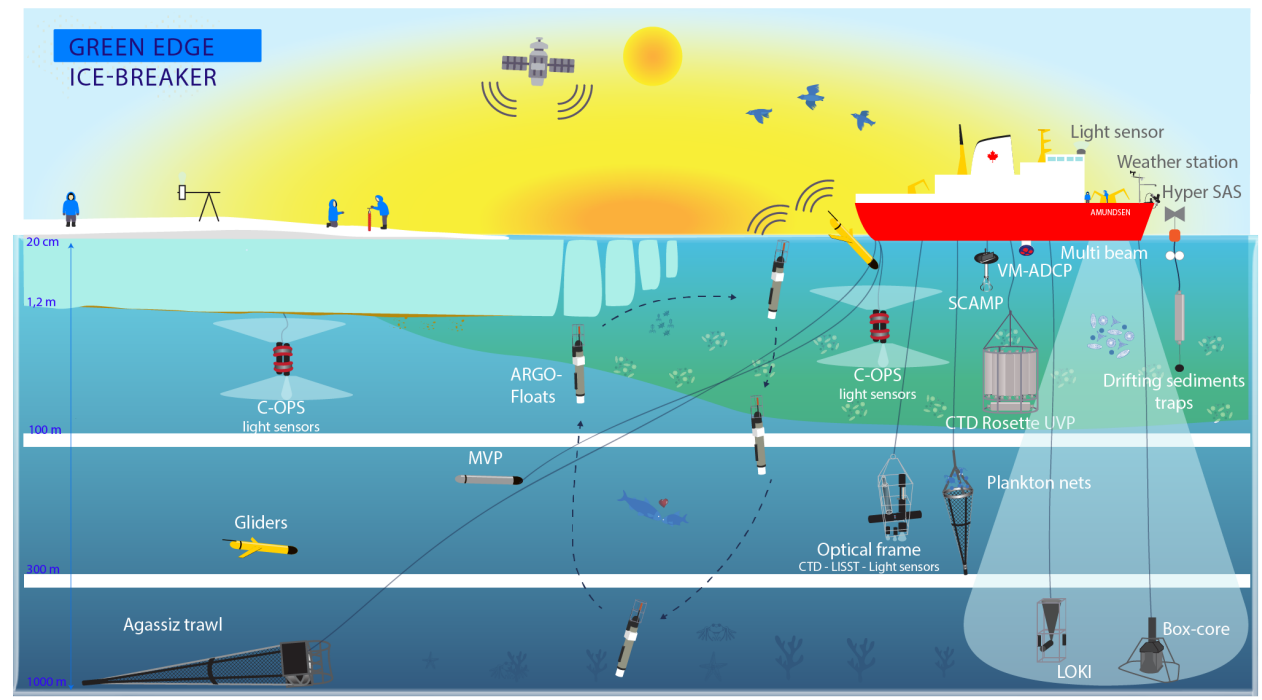

Figure 2: Representation of all operations carried out during the Green Edge campaign. 


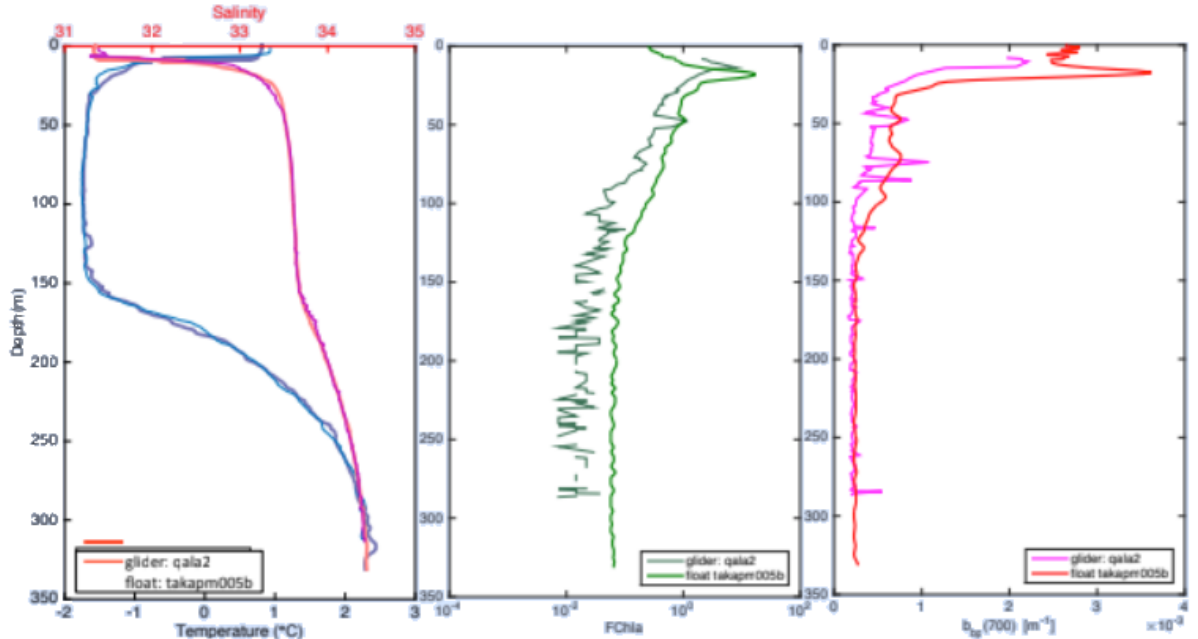

Figure 3: Comparison between salinity (psu), temperature $\left({ }^{\circ} \mathrm{C}\right)$, chlorophyll fluorescence (relative units) and backscattering at 700 $\mathrm{nm}\left(\mathrm{bbp}(\mathbf{7 0 0}), \mathrm{m}^{-1}\right)$ data from the qala2 glider and the takapm005b BioArgo float at their closest common position (Fig. 1B). 
https://doi.org/10.5194/essd-2022-41

Preprint. Discussion started: 21 February 2022

(c) Author(s) 2022. CC BY 4.0 License.

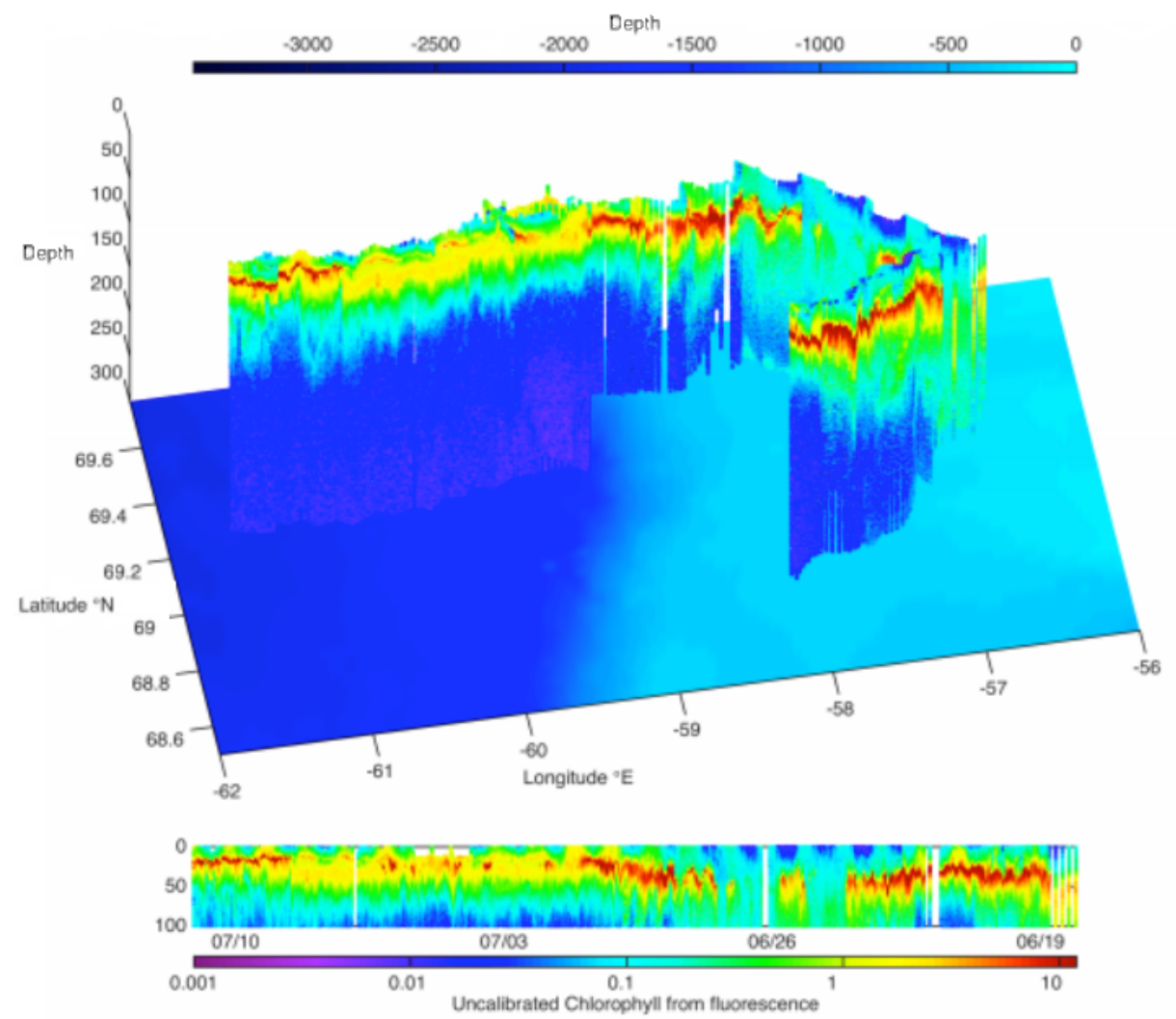

700

Figure 4: Chlorophyll fluorescence measured by the Glider qala2 during its 23-day journey (Fig. 1B). 
https://doi.org/10.5194/essd-2022-41

Preprint. Discussion started: 21 February 2022

(c) Author(s) 2022. CC BY 4.0 License.
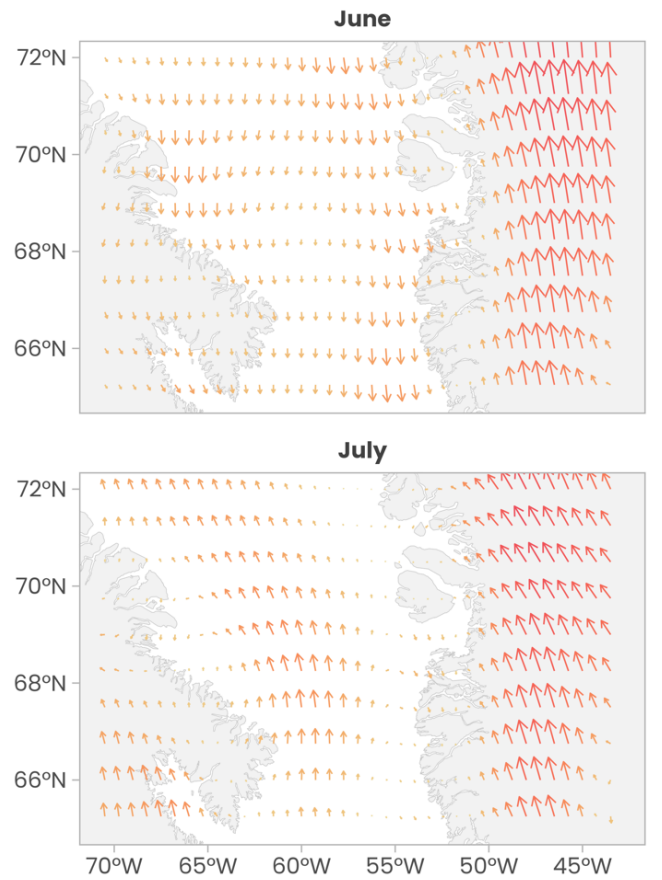

Wind speed $\left(\mathrm{m} \mathrm{s}^{-1}\right)$

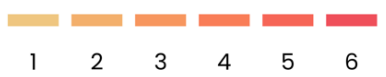

705 Figure 5: Average wind direction and speed (arrow length) over Baffin Bay in June 2016 (top panel) and July 2016 (bottom panel); CCMP wind vector analysis product (V2.0, Atlas et al., (2011)). 
https://doi.org/10.5194/essd-2022-41

Preprint. Discussion started: 21 February 2022

(c) Author(s) 2022. CC BY 4.0 License.
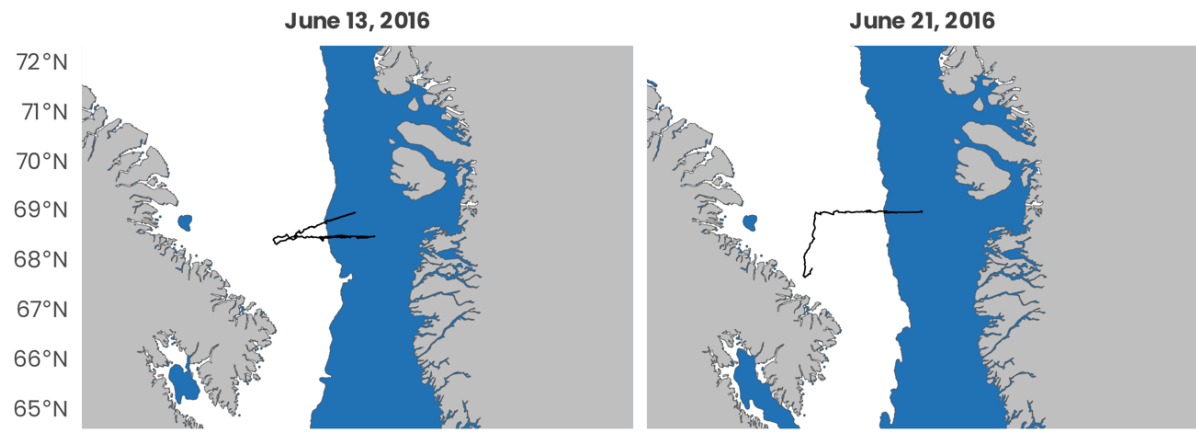

June 29, 2016

July 07, 2016
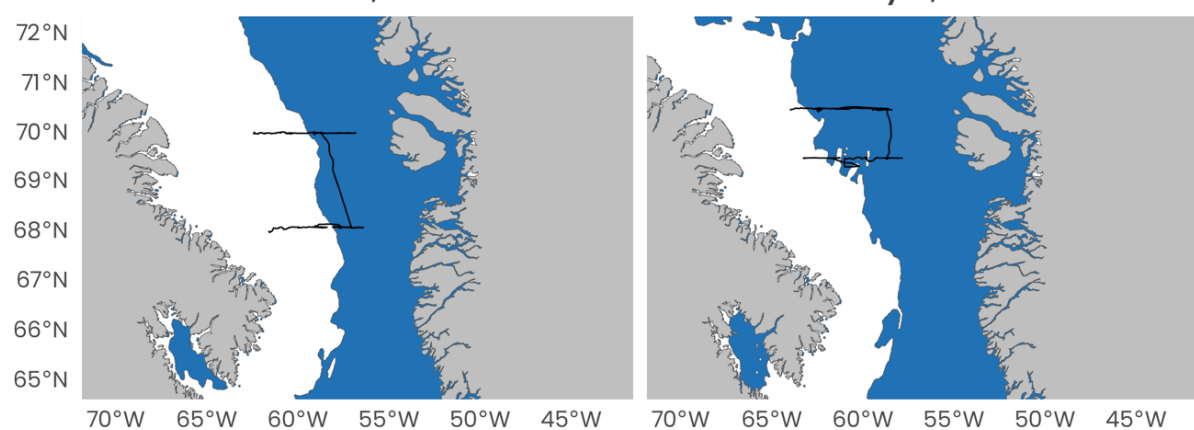

Figure 6: Average weekly sea-ice extent for each of the four 8-day periods during the Green Edge cruise. Date is the median date of

the 8-days sampling period. The white areas represent sea ice and the blue areas the open water. 
https://doi.org/10.5194/essd-2022-41

Preprint. Discussion started: 21 February 2022

(c) Author(s) 2022. CC BY 4.0 License.

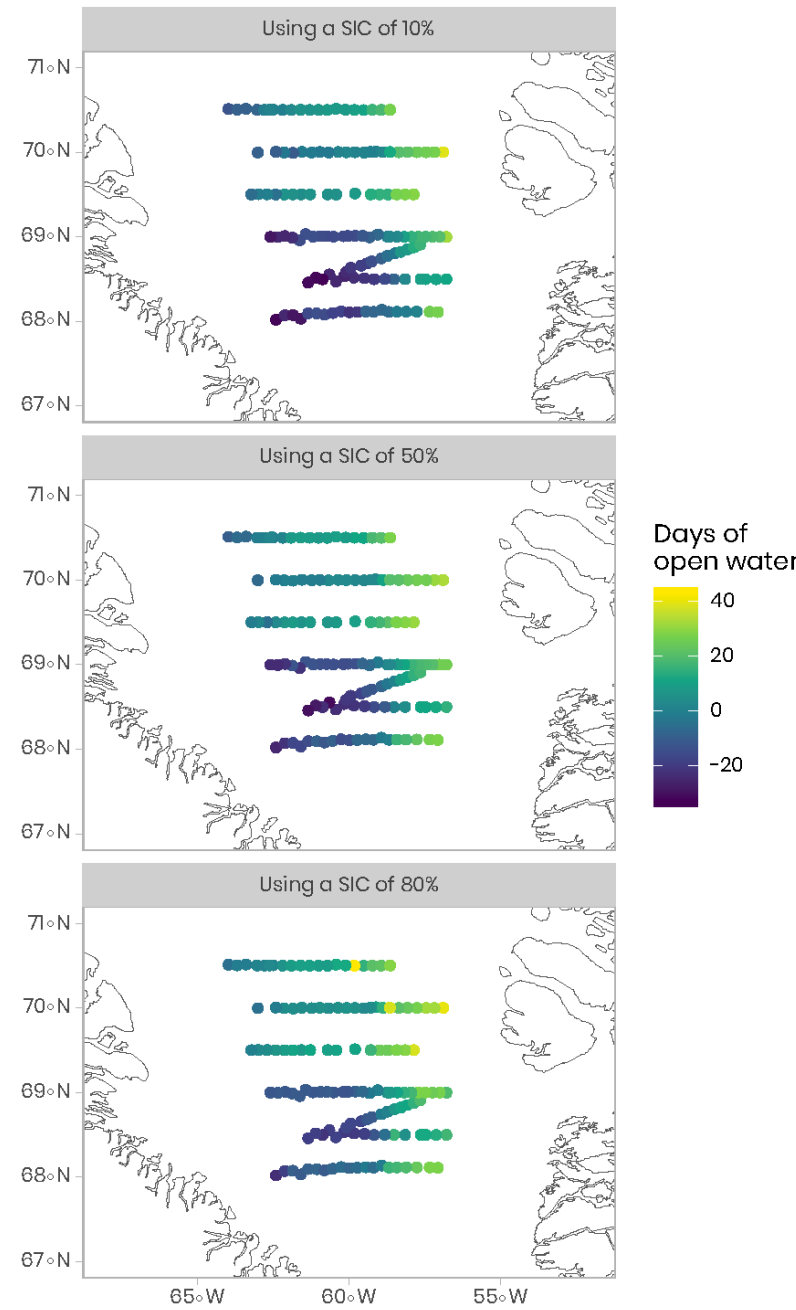

Figure 7: Open water days (OWD) before sampling (values in days). The yellow colour corresponds to positive values meaning the water was already free of ice on the day of sampling. Bluer darker values correspond to stations that were still covered in ice at sampling date (negative values). Values of OWD can be computed using different SIC (sea-ice coverage) values: top panel SIC = $10 \%$, middle panel SIC $=50 \%$ and bottom panel SIC $=\mathbf{8 0} \%$. 

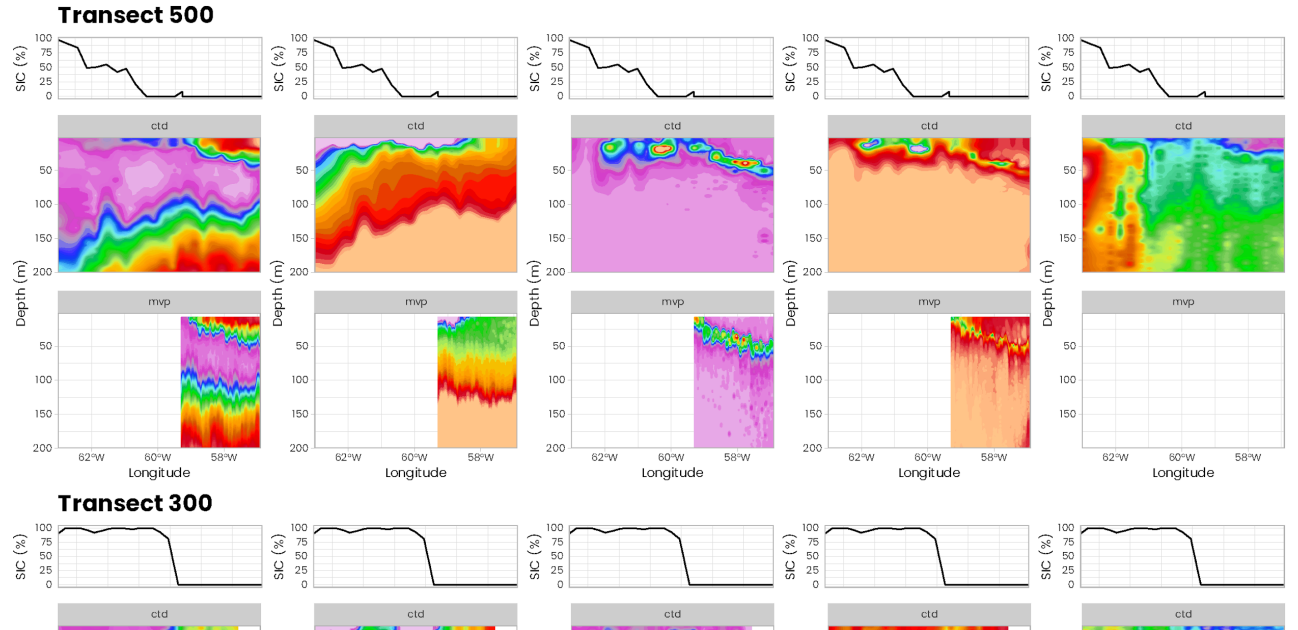

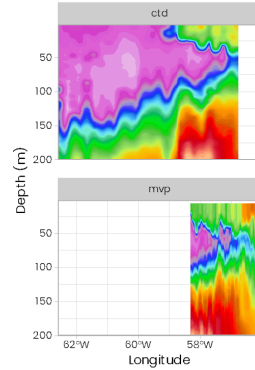

Temperature $\left({ }^{\circ} \mathrm{C}\right)$

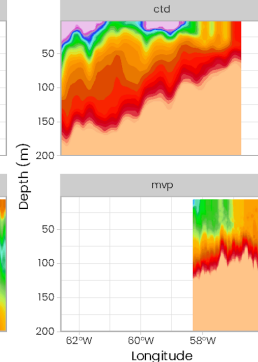

Salinity $\left(\mathrm{g} \mathrm{kg}^{-1}\right)$

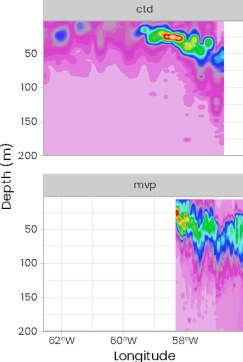

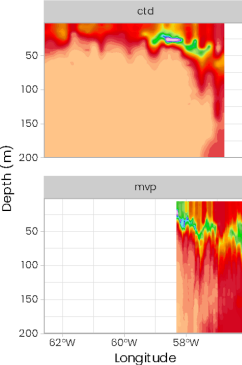

Transmittance (\%)

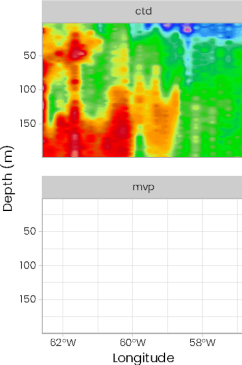

$\operatorname{CDOM}\left(\mathrm{mg} \mathrm{m}^{-3}\right)$

Figure 8: Physical properties of seawater along transects $500\left(70^{\circ}\right.$ North $)$ and $300\left(69^{\circ}\right.$ North). Middle and bottom panels show data recorded by sensors deployed on the rosette and on the MVP, respectively. From left to right: temperature $\left({ }^{\circ} \mathrm{C}\right)$, salinity $(\mathrm{g} / \mathrm{Kg})$, chlorophyll a concentration $\left(\mathrm{mg} \mathrm{m}^{-3}\right)$, transmittance $(\%)$ and CDOM concentration $\left(\mathrm{mg} \mathrm{m}^{-3}\right)$ as a function of depth $(\mathrm{m}, \mathrm{y}$ axis) and longitude (degrees West, $x$ axis). Topmost panel shows ice coverage (\%) at corresponding longitudes. 
https://doi.org/10.5194/essd-2022-41

Preprint. Discussion started: 21 February 2022

(c) Author(s) 2022. CC BY 4.0 License.

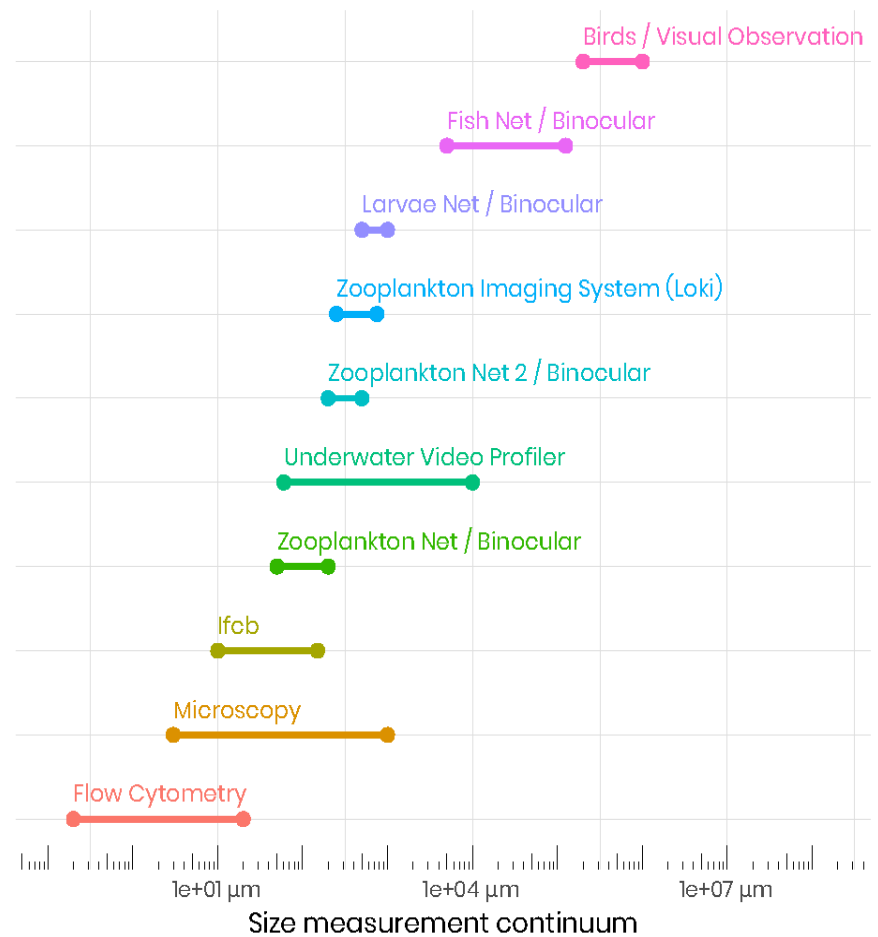

Figure 9: Schematic of the biological sampling size continuum across the various methods and tools used during the Green Edge cruise. 

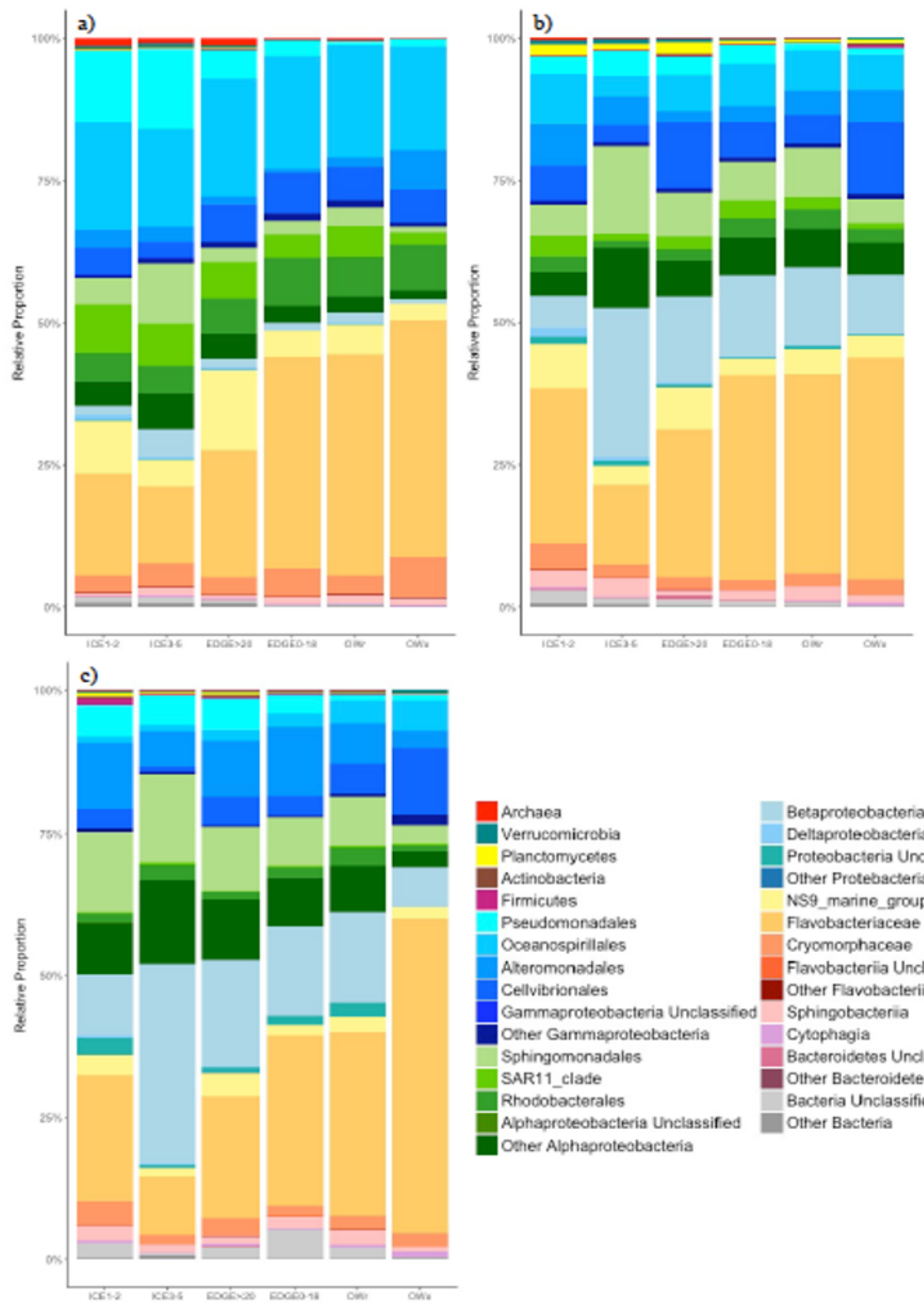

\begin{tabular}{|c|c|}
\hline Archa & Betaprotecobacteria \\
\hline microbia & Deltaprotecbacteria \\
\hline Planctomycetes & Proteobacteria Unclassifiec \\
\hline Actinobacteria & Other Protebacteria \\
\hline Firmicutes & NS9_marine_group \\
\hline Pseudomonadales & Flavobacteriacese \\
\hline Oceanospirilales & Cryomorphaceae \\
\hline Ateromonadales & Flavobacterila Unclassified \\
\hline Cellvibrionales & Other Flavobacteriia \\
\hline Gammaproteobacteria Unclassified & Sphingobacteria \\
\hline |Oener Gammaproteobacteria & Cyophagia \\
\hline Sphingomonadales & Bacteroidetes Unclassifed \\
\hline SAR11_clade & Other Bacteroideses \\
\hline Rhodobacterales & Bacteria Unclassified \\
\hline Alphaproteobacteria Unclassifed & Other Bacteria \\
\hline
\end{tabular}

Figure 10: Relative proportions of the different taxa within the different groups of samples, (a) for the 0.2-3 $\mu \mathrm{m}$ fraction, (b) for the 3-20 $\mu \mathrm{m}$ fraction and (c) for the fraction $>20 \mu \mathrm{m}$. ICE1-2: Ice stations in the T100 and T200 transects ; ICE3-5: Ice stations in T300 and T500 transects; EDGE0-18: Samples between 0 and $18 \mathrm{~m}$ depth from the edge stations; EDGE $>20$ : Samples greater than $20 \mathrm{~m}$ deep from the edge stations; OWr: Open water stations where the ice had receded between 2 and 8 days previously; OWo: Open water stations where the ice has receded more than 15 days previously. 
https://doi.org/10.5194/essd-2022-41

Preprint. Discussion started: 21 February 2022

(c) Author(s) 2022. CC BY 4.0 License.
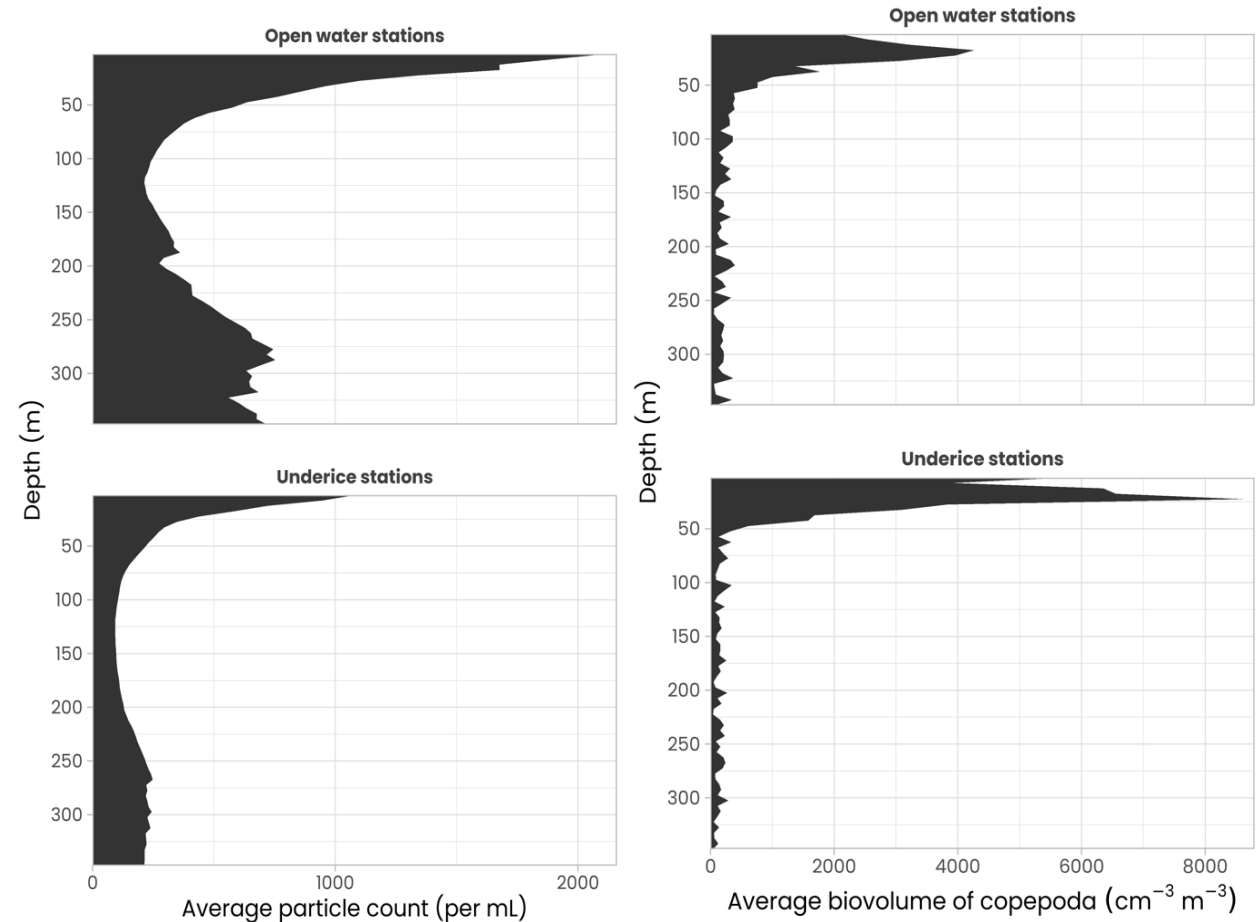

740 Figure 11: Underwater Vision Profiler data. Average vertical profiles of particle concentration (per ml; left panels) and Copepod volumetric fraction $\left(\mathrm{cm}^{3} \mathrm{~m}^{-3}\right.$; right panels) at open-water (top panels) and ice-covered (bottom panels) stations over the top $350 \mathrm{~m}$ of the water column. 


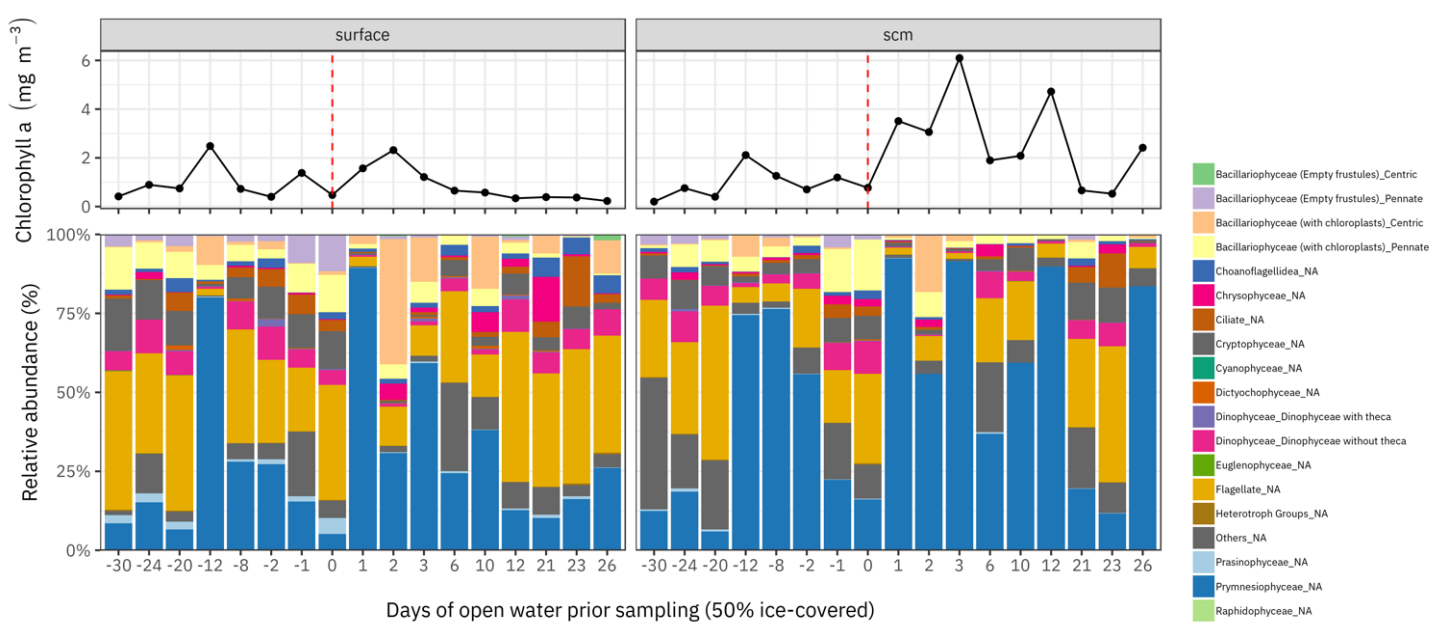

745 Figure 12: Relative abundance (\%) of main phytoplankton groups (colored bars) at the surface (left) and at the subsurface chlorophyll maximum (SCM; right) for all stations analyzed. Stations are sorted according to their OWD value (Fig. 7). Top panel represents the chlorophyll a concentration $\left(\mathrm{mg} \mathrm{m}^{-3}\right)$ at the relevant depths for each station. 

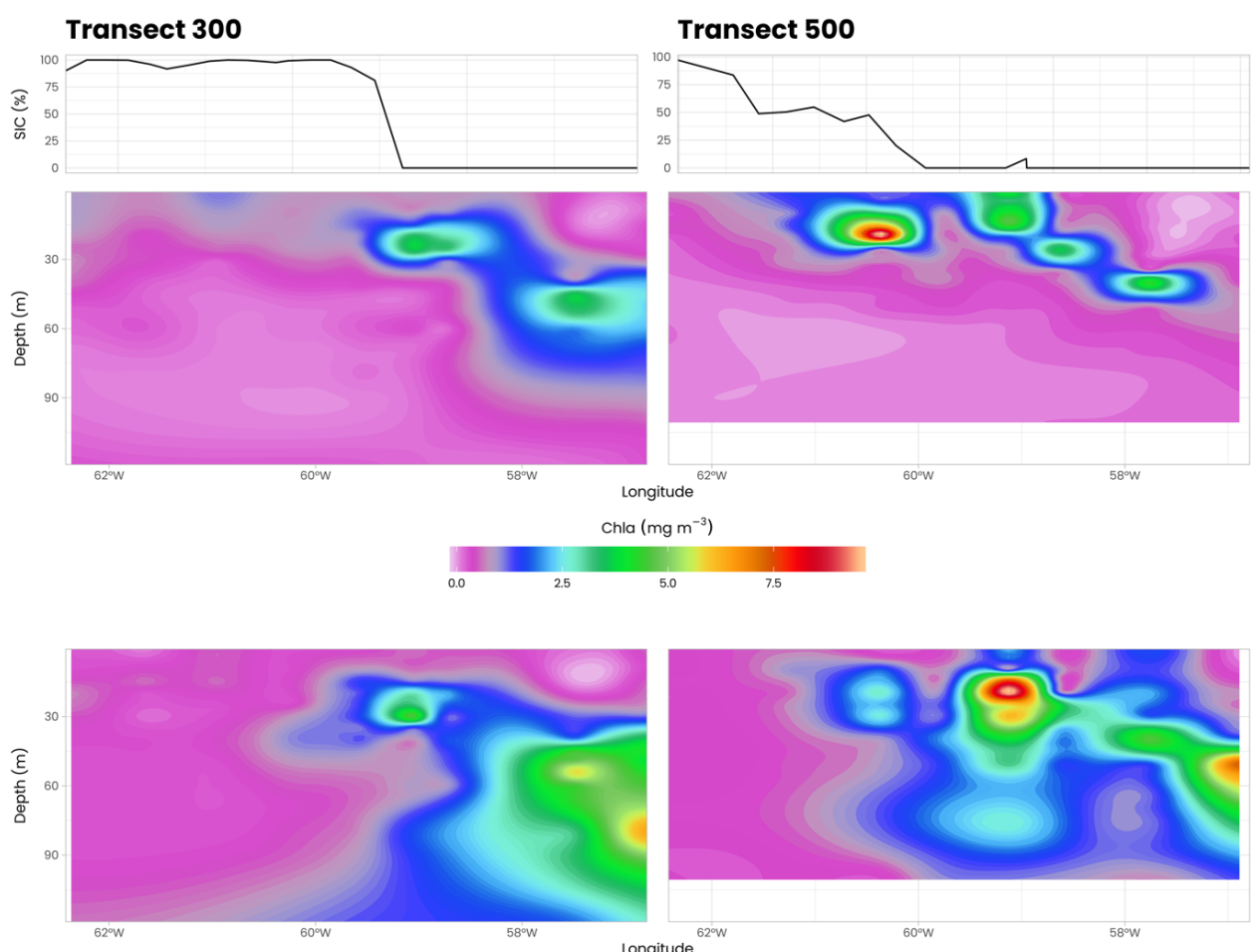

Total phaeophorbid concentration $\left(\mathrm{mg} \mathrm{m}^{-3}\right)$
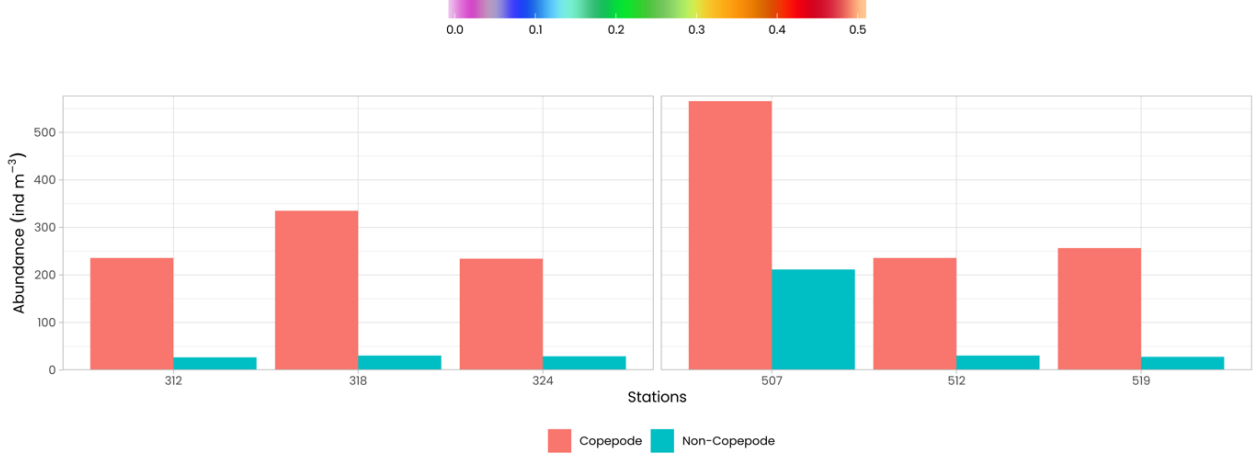

750 Figure 13: Water column chlorophyll a concentration (a) $\mathbf{m g ~ m}^{-3}$, top panels), and total phaeophorbid a concentration (b) $\mathbf{m g ~ m}^{-3}$, bottom panels) along transects $300\left(69^{\circ}\right.$ North, left panels) and 500 ( $\left(70^{\circ}\right.$ North, right panels), as measured by HPLC on discrete samples obtained from the Niskin bottles at every FULL and BASIC station. C, Abundance of zooplankton (ind $\mathrm{m}^{-3}$ ), Copepods in red and non-copepods in blue) at each of the three FULL stations sampled on each transect. The top graph indicates the SIC at each station at the time of sampling. 


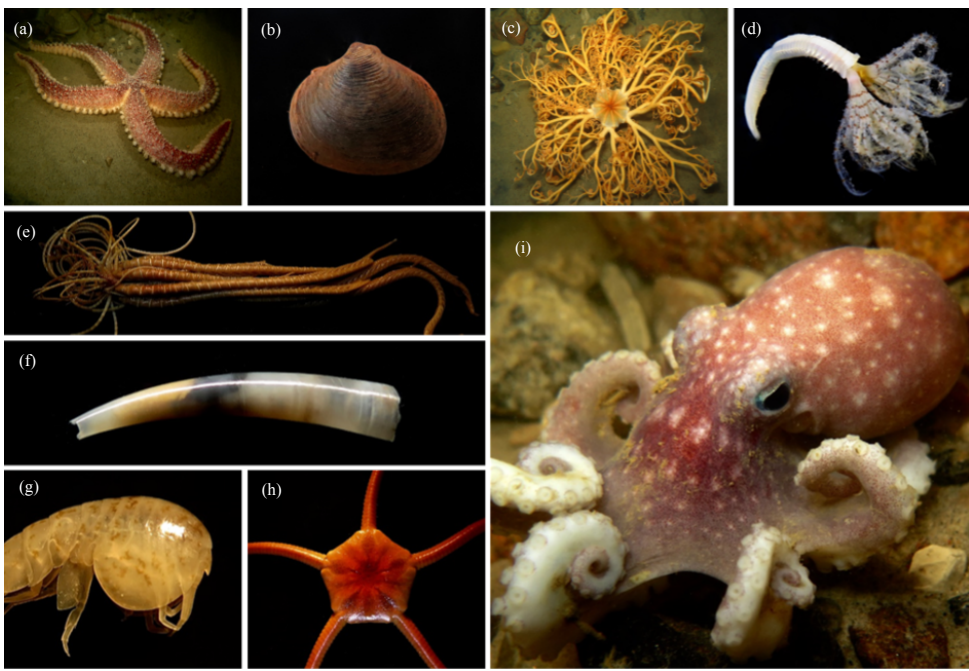

Figure 14: Examples of benthic organisms. From left to right, top to bottom: (a) Urasterias lincki, (b) Astarte borealis, (c) Gorgonocephalus eucnemis, (e) Brachiomma sp., (f) Heliometra glacialis, (g) Siphonodentalium lobatum, (h) Stegocephalus inflatus, (i) Ophiopleura borealis, Bathypolypus sp. (pictures by benthic ecology lab Université Laval, Gonzalo Bravo). 


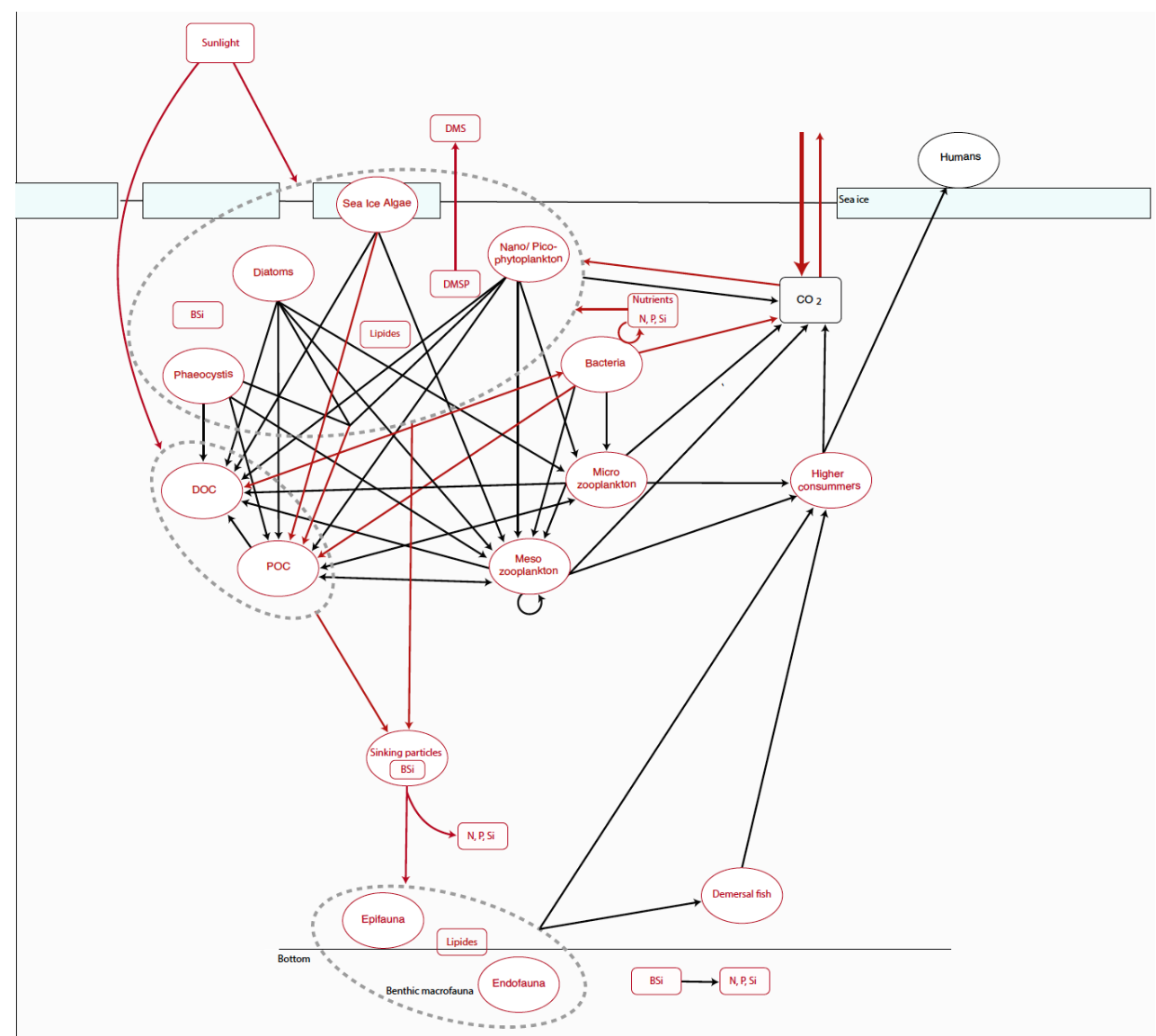

Figure 15: Schematic representation of all stocks (bubbles) and fluxes (arrows) measured during the Green Edge cruise as part of the MIZ trophic system. Measured and calculated parameters are represented in red. 
https://doi.org/10.5194/essd-2022-41

Preprint. Discussion started: 21 February 2022

(c) Author(s) 2022. CC BY 4.0 License.

Table 1: List of operations carried out during the Amundsen Green Edge cruise at each different station type. [(+) opportunistic sampling only]. CTD conductivity temperature depth, AOP apparent optical properties, IOP inherent optical properties, SCAMP self-contained autonomous microprofiler, LOKI lightframe onsight key species Investigation.

\begin{tabular}{|c|c|c|c|c|}
\hline OPERATION TYPE & FULL & BASIC & NUT & CTD \\
\hline CTD cast & + & + & + & + \\
\hline Water sampling (niskin/rosette) & + & + & + & \\
\hline AOP profile & + & + & & \\
\hline IOP profile & + & & & \\
\hline SCAMP profile & + & & & \\
\hline $\begin{array}{l}\text { LOKI and vertical integrated } \\
\text { Plankton nets }\end{array}$ & + & & & \\
\hline Mesozoic plankton trawl net & + & & & \\
\hline Hydrobios & + & & & \\
\hline Beam trawl & + & $(+)$ & & \\
\hline Agassiz trawl & + & & & \\
\hline Box core & + & $(+)$ & & \\
\hline Ice sampling (when ice covered) & + & & & \\
\hline TOTAL & 26 & 18 & 49 & 51 \\
\hline
\end{tabular}


https://doi.org/10.5194/essd-2022-41

Preprint. Discussion started: 21 February 2022

(c) Author(s) 2022. CC BY 4.0 License.

Table 2: List of the sensors attached to the rosette carousel. CDOM colored dissolved organic matter, PAR photosynthetic available radiation, ADCP Acoustic doppler current profiler.

\begin{tabular}{|c|c|c|c|c|c|}
\hline SENSOR & TYPE & UNIT & SERIAL \# & CALIBRATION & \# CASTS \\
\hline Temperature & SBE 3plus & $\begin{array}{c}\text { ITS-90 } \\
\operatorname{deg} \text { C }\end{array}$ & $03 \mathrm{P} 4318$ & $12 / 2015$ & 203 \\
\hline Conductivity & SBE 4 & $\mathrm{mS} / \mathrm{cm}$ & 42696 & $12 / 2015$ & 203 \\
\hline Pressure & $\begin{array}{c}\text { Paroscientific } \\
\text { Digiquartz }{ }^{\circledR}\end{array}$ & $\mathrm{db}$ & 679 & $01 / 2016$ & 203 \\
\hline Oxygen & SBE 43 & $\mathrm{~mL} / \mathrm{L}$ & 430427 & $12 / 2015$ & 203 \\
\hline CDOM & WetLabs & $\mathrm{mg} / \mathrm{m}^{3}$ & 2344 & $01 / 2016$ & 203 \\
\hline Fluorescence & Seapoint & $\mu \mathrm{g} / \mathrm{L}$ & 3120 & $01 / 2016$ & 203 \\
\hline Transmissometer & WetLabs C-Star & $\%$ & CST671DR & $01 / 2016$ & 87 \\
\hline Sonar Altimeter & Benthos PSA-916 & $\mathrm{m}$ & 1065 & $02 / 2016$ & 203 \\
\hline PAR / Irradiance & $\begin{array}{c}\text { QCP-2300 } \\
\text { Biospherical Instr. }\end{array}$ & $\mu \mathrm{Em}^{-2} \mathrm{~s}^{-1}$ & 4664 & $01 / 2014$ & 203 \\
\hline Nitrate & $\begin{array}{c}\text { MBARI-ISUS } \\
\text { Satlantic }\end{array}$ & $\mu \mathrm{M}$ & 132 & $05 / 2016$ & 104 \\
\hline$L-A D C P$ & WHM300-RDI & NS & & $03 / 2016$ & 203 \\
\hline
\end{tabular}


Table 3. List of all the variables sampled during the Amundsen Green Edge cruise.

\begin{tabular}{|c|c|c|c|c|}
\hline VARIABLE & METHOD & $\begin{array}{l}\text { SAMPLING } \\
\text { METHOD }\end{array}$ & PI & $\begin{array}{l}\text { AVAILAB } \\
\text { LE }\end{array}$ \\
\hline $\begin{array}{l}{ }^{15} \mathrm{~N} \text {-nitrate } \\
\text { assimilation }\end{array}$ & ${ }^{15} \mathrm{~N}$ spiking - mass-spectrometry & $\begin{array}{l}\text { Rosette Deck } \\
\text { incubations }\end{array}$ & Tremblay J. E. & Yes \\
\hline $\begin{array}{l}{ }^{15} \mathrm{~N} \text {-nitrate primary } \\
\text { production }(13 \mathrm{C})\end{array}$ & ${ }^{15} \mathrm{~N}$ spiking - mass-spectrometry & $\begin{array}{l}\text { Rosette Deck } \\
\text { incubations }\end{array}$ & Tremblay J. E. & Yes \\
\hline${ }^{15} \mathrm{~N}$-urea assimilation & ${ }^{15} \mathrm{~N}$ spiking - mass-spectrometry & $\begin{array}{l}\text { Rosette Deck } \\
\text { incubations }\end{array}$ & $\begin{array}{l}\text { Raimbault P. / } \\
\text { Garcia N. }\end{array}$ & Yes \\
\hline $\begin{array}{l}\text { Above water } \\
\text { reflectance }(\operatorname{Rrs}(0+))\end{array}$ & C-OPS & Profile mode & Belanger S. & Yes \\
\hline $\begin{array}{l}\text { Above water } \\
\text { reflectance }(\operatorname{Rrs}(0+))\end{array}$ & HyperSAS & $\begin{array}{l}\text { Above-water } \\
\text { sensor }\end{array}$ & Belanger S. & Yes \\
\hline $\begin{array}{l}\text { Absorption (non algal } \\
\text { particles) }\end{array}$ & Spectrophotometer (filters) & $\begin{array}{l}\text { Rosette water } \\
\text { sample }\end{array}$ & $\begin{array}{l}\text { Bricaud A. / } \\
\text { Sciandra A. / } \\
\text { Matsuoka A. }\end{array}$ & Yes \\
\hline $\begin{array}{l}\text { Absorption } \\
\text { (particulate matter) }\end{array}$ & Spectrophotometer (filters) & $\begin{array}{l}\text { Rosette water } \\
\text { sample }\end{array}$ & $\begin{array}{l}\text { Bricaud A. / } \\
\text { Sciandra A. / } \\
\text { Matsuoka A. }\end{array}$ & Yes \\
\hline $\begin{array}{l}\text { Absorption coefficient } \\
\text { (total) }\end{array}$ & a-sphere & $\begin{array}{l}\text { In-water } \\
\text { profiler }\end{array}$ & Belanger S. & Yes \\
\hline $\begin{array}{l}\text { Acoustic } \\
\text { determination of fish } \\
\text { presence }\end{array}$ & Echosounder & $\begin{array}{l}\text { Continuous } \\
\text { on way }\end{array}$ & Fortier L. & Yes \\
\hline $\begin{array}{l}\text { Current speed and } \\
\text { direction }\end{array}$ & $\begin{array}{l}\text { Acoustic doppler current profiler } \\
(\mathrm{ADCP})(150 \mathrm{kHz})\end{array}$ & $\begin{array}{l}\text { Continuous } \\
\text { horizontal }\end{array}$ & $\begin{array}{l}\text { Guillot P. / } \\
\text { Gombault C. }\end{array}$ & Yes \\
\hline $\begin{array}{l}\text { Current speed and } \\
\text { direction }\end{array}$ & ADCP (LADCP) & $\begin{array}{l}\text { In-water } \\
\text { profiler }\end{array}$ & $\begin{array}{l}\text { Guillot P. / } \\
\text { Gombault C. }\end{array}$ & Yes \\
\hline Air relative humidity & Humidity Sensor & $\begin{array}{l}\text { Meteorologic } \\
\text { al Tower }\end{array}$ & $\begin{array}{l}\text { Else B. / } \\
\text { Burgers T. }\end{array}$ & Yes \\
\hline Air temperature & Temperature probe & $\begin{array}{l}\text { Meteorologic } \\
\text { al Tower }\end{array}$ & $\begin{array}{l}\text { Else B. / } \\
\text { Burgers T. }\end{array}$ & Yes \\
\hline $\begin{array}{l}\text { Ammonium } \\
\text { (assimilation) }\end{array}$ & Isotopic dilution ${ }^{15} \mathrm{~N}$ & $\begin{array}{l}\text { Rosette Deck } \\
\text { incubations }\end{array}$ & $\begin{array}{l}\text { Raimbault P. / } \\
\text { Garcia N. }\end{array}$ & Yes \\
\hline $\begin{array}{l}\text { Ammonium } \\
\text { (regeneration) }\end{array}$ & Isotopic dilution ${ }^{15} \mathrm{~N}$ & $\begin{array}{l}\text { Rosette Deck } \\
\text { incubations }\end{array}$ & $\begin{array}{l}\text { Raimbault P. / } \\
\text { Garcia N. }\end{array}$ & Yes \\
\hline
\end{tabular}




\begin{tabular}{|c|c|c|c|c|}
\hline $\begin{array}{l}\text { Ammonium } \\
\text { concentration }\end{array}$ & Fluorescence & $\begin{array}{l}\text { Rosette water } \\
\text { sample }\end{array}$ & Tremblay J. E. & Yes \\
\hline $\begin{array}{l}\text { Backscattering } \\
\text { coefficient }\end{array}$ & Bio-Argo profiler & $\begin{array}{l}\text { In-water } \\
\text { profiler }\end{array}$ & Babin M. & Yes \\
\hline $\begin{array}{l}\text { Backscattering } \\
\text { coefficient ( } 6 \\
\text { wavelength) }\end{array}$ & Backscattering meter & $\begin{array}{l}\text { In-water } \\
\text { profiler }\end{array}$ & Belanger S. & Yes \\
\hline Bacteria abundance & Flow Cytometry & $\begin{array}{l}\text { Rosette water } \\
\text { sample }\end{array}$ & Vaulot D. & Yes \\
\hline $\begin{array}{l}\text { Bacteria infected by } \\
\text { virus }\end{array}$ & Electron Microscopy & $\begin{array}{l}\text { Rosette water } \\
\text { sample }\end{array}$ & Joux F. & Yes \\
\hline Bacterial diversity & $\begin{array}{l}16 \mathrm{~S} \text { rRNA/DNA amplicon } \\
\text { sequencing }\end{array}$ & $\begin{array}{l}\text { Rosette water } \\
\text { sample }\end{array}$ & Joux F. & Yes \\
\hline Bacterial production & Leucine- ${ }^{3} \mathrm{H}$ incorporation & $\begin{array}{l}\text { Rosette water } \\
\text { sample }\end{array}$ & Joux F. & Yes \\
\hline $\begin{array}{l}\text { Bacterial respiration } \\
\text { (whole community) }\end{array}$ & $\begin{array}{l}\mathrm{O}_{2} \text { consumption - Winkler - } \\
\text { Incubations }\end{array}$ & $\begin{array}{l}\text { Rosette water } \\
\text { sample }\end{array}$ & Joux F. & Yes \\
\hline $\begin{array}{l}\text { Bacterial salinity-and } \\
\text { light-induced stress }\end{array}$ & $\begin{array}{l}\text { Gas Chromatography - Mass } \\
\text { Spectrometry }\end{array}$ & $\begin{array}{l}\text { Rosette water } \\
\text { sample }\end{array}$ & $\begin{array}{l}\text { Rontani J.-F. / } \\
\text { Amiraux R. / } \\
\text { Burot C. }\end{array}$ & Yes \\
\hline Bacterial viability & Incubation & $\begin{array}{l}\text { Rosette water } \\
\text { sample }\end{array}$ & $\begin{array}{l}\text { Rontani J.-F. / } \\
\text { Amiraux R. / } \\
\text { Burot C. }\end{array}$ & Yes \\
\hline Bathymetry & EM302 multi-beam echosounder & $\begin{array}{l}\text { Continuous } \\
\text { horizontal }\end{array}$ & $\begin{array}{l}\text { Lajeunesse P. / } \\
\text { Joyal G. / } \\
\text { Brouard E. }\end{array}$ & Yes \\
\hline $\begin{array}{l}\text { Benthic ammonium } \\
\text { flux }\end{array}$ & Incubations - Colorimetry & Box corer & Morata N. & Yes \\
\hline $\begin{array}{l}\text { Benthic macrofauna } \\
\text { abundance }\end{array}$ & Microscopy & Box corer & Archambault P. & Yes \\
\hline $\begin{array}{l}\text { Benthic macrofauna } \\
\text { biomass }\end{array}$ & Wet weight & Box corer & Archambault P. & Yes \\
\hline $\begin{array}{l}\text { Benthic macrofauna } \\
\text { diversity }\end{array}$ & Microscopy & Box corer & Archambault P. & Yes \\
\hline Benthic nitrate flux & $\begin{array}{l}\text { Incubations - Colorimetry- } \\
\text { Autoanalyzer }\end{array}$ & Box corer & Morata N. & Yes \\
\hline
\end{tabular}




\begin{tabular}{|c|c|c|c|c|}
\hline Benthic nitrite flux & $\begin{array}{l}\text { Incubations - Colorimetry- } \\
\text { Autoanalyzer }\end{array}$ & Box corer & Morata N. & Yes \\
\hline $\begin{array}{l}\text { Benthic phosphate } \\
\text { flux }\end{array}$ & $\begin{array}{l}\text { Incubations - Colorimetry- } \\
\text { Autoanalyzer }\end{array}$ & Box corer & Morata N. & Yes \\
\hline $\begin{array}{l}\text { Benthic silicic acid } \\
\text { flux }\end{array}$ & $\begin{array}{l}\text { Incubations - Colorimetry - } \\
\text { Autoanalyzer }\end{array}$ & Box corer & Morata N. & Yes \\
\hline $\begin{array}{l}\text { Benthic carbon } \\
\text { content }\end{array}$ & $\mathrm{CN}$ analyser & Box corer & Morata N. & Yes \\
\hline $\begin{array}{l}\text { Chlorophyll a and } \\
\text { phaeopigments } \\
\text { concentration }\end{array}$ & Fluorimetry & Sea ice core & $\begin{array}{l}\text { Bruyant F./ } \\
\text { Babin M. }\end{array}$ & Yes \\
\hline $\begin{array}{l}\text { Chlorophyll a and } \\
\text { phaeopigments } \\
\text { concentration }\end{array}$ & Fluorimetry & $\begin{array}{l}\text { Rosette water } \\
\text { sample }\end{array}$ & $\begin{array}{l}\text { Bruyant F./ } \\
\text { Babin M. }\end{array}$ & Yes \\
\hline $\begin{array}{l}\text { Chlorophyll a and } \\
\text { phaeopigments } \\
\text { concentration } \\
\text { (benthic) }\end{array}$ & Fluorometric analysis & Box corer & Archambault P. & Yes \\
\hline $\begin{array}{l}\text { Chlorophyll a and } \\
\text { phaeopigments } \\
\text { concentration } \\
\text { (benthic) }\end{array}$ & Fluorometric analysis & Box corer & Morata N. & Yes \\
\hline $\begin{array}{l}\text { Chlorophyll a } \\
\text { fluorescence }\end{array}$ & Fluorometer & $\begin{array}{l}\text { In-water } \\
\text { profiler }\end{array}$ & $\begin{array}{l}\text { Guillot P. / } \\
\text { Gombault C. }\end{array}$ & Yes \\
\hline $\begin{array}{l}\text { Chlorophyll a } \\
\text { fluorescence }\end{array}$ & Fluorescence & $\begin{array}{l}\text { In-water } \\
\text { profiler }\end{array}$ & Belanger S. & Yes \\
\hline $\begin{array}{l}\text { Chlorophyll a } \\
\text { fluorescence }\end{array}$ & Fluorometer & $\begin{array}{l}\text { Continuous } \\
\text { horizontal }\end{array}$ & $\begin{array}{l}\text { Guillot P. / } \\
\text { Gombault C. }\end{array}$ & Yes \\
\hline $\begin{array}{l}\text { Chlorophyll a } \\
\text { fluorescence }\end{array}$ & Bio-Argo profiler & $\begin{array}{l}\text { In-water } \\
\text { profiler }\end{array}$ & Babin M. & Yes \\
\hline $\begin{array}{l}\text { Chlorophyll a } \\
\text { fluorescence }\end{array}$ & FLRTD sensor & $\begin{array}{l}\text { Moving } \\
\text { Vessel } \\
\text { Profiler }\end{array}$ & $\begin{array}{l}\text { Morisset S. / } \\
\text { Gombault C. }\end{array}$ & Yes \\
\hline $\begin{array}{l}\text { Chlorophyll-a } \\
\text { concentration }\end{array}$ & Fluorometer & $\begin{array}{l}\text { Drifting } \\
\text { sediment trap }\end{array}$ & Lalande C. & Yes \\
\hline $\begin{array}{l}\text { Chromophoric } \\
\text { dissolved organic } \\
\text { matter absorption }\end{array}$ & Ultrapath & $\begin{array}{l}\text { Rosette water } \\
\text { sample }\end{array}$ & Matsuoka A. & Yes \\
\hline
\end{tabular}




\begin{tabular}{|c|c|c|c|c|}
\hline $\begin{array}{l}\text { Chromophoric } \\
\text { dissolved organic } \\
\text { matter fluorescence }\end{array}$ & Fluorescence (Wetlabs) & $\begin{array}{l}\text { In-water } \\
\text { profiler }\end{array}$ & Belanger S. & Yes \\
\hline $\begin{array}{l}\text { Chromophoric } \\
\text { dissolved organic } \\
\text { matter fluorescence }\end{array}$ & Fluorescence (Wetlabs, rosette) & $\begin{array}{l}\text { In-water } \\
\text { profiler }\end{array}$ & $\begin{array}{l}\text { Guillot P. / } \\
\text { Gombault C. }\end{array}$ & Yes \\
\hline $\begin{array}{l}\text { Chromophoric } \\
\text { dissolved organic } \\
\text { matter fluorescence }\end{array}$ & BGC-Argo profiler & $\begin{array}{l}\text { In-water } \\
\text { profiler }\end{array}$ & Babin M. & Yes \\
\hline $\begin{array}{l}\mathrm{CO}_{2} \text { partial pressure } \\
\left(\mathrm{pCO}_{2}\right)\end{array}$ & LiCOR/General Oceanics & $\begin{array}{l}\text { Continuous } \\
\text { horizontal }\end{array}$ & $\begin{array}{l}\text { Else B. / } \\
\text { Burgers T. }\end{array}$ & Yes \\
\hline $\begin{array}{l}\text { Conductivity, } \\
\text { temperature and depth } \\
\text { (CTD) }\end{array}$ & Sea-Bird (IOP optical frame) & $\begin{array}{l}\text { In-water } \\
\text { profiler }\end{array}$ & Belanger S. & Yes \\
\hline $\begin{array}{l}\text { Conductivity, } \\
\text { temperature and depth } \\
\text { (CTD) }\end{array}$ & Sea-Bird (rosette) & $\begin{array}{l}\text { In-water } \\
\text { profiler }\end{array}$ & $\begin{array}{l}\text { Guillot P. / } \\
\text { Gombault C. }\end{array}$ & Yes \\
\hline $\begin{array}{l}\text { Conductivity, } \\
\text { temperature and depth } \\
\text { (CTD) }\end{array}$ & Sea-Bird & $\begin{array}{l}\text { Continuous } \\
\text { horizontal }\end{array}$ & $\begin{array}{l}\text { Guillot P. / } \\
\text { Gombault C. }\end{array}$ & Yes \\
\hline $\begin{array}{l}\text { Conductivity, } \\
\text { temperature and depth } \\
\text { (CTD) }\end{array}$ & BGC-Argo profiler & $\begin{array}{l}\text { In-water } \\
\text { profiler }\end{array}$ & Babin M. & Yes \\
\hline $\begin{array}{l}\text { Conductivity, } \\
\text { temperature and depth } \\
\text { (CTD) }\end{array}$ & AML micro CTD & $\begin{array}{l}\text { Moving } \\
\text { Vessel } \\
\text { Profiler }\end{array}$ & $\begin{array}{l}\text { Morisset S. / } \\
\text { Gombault C. }\end{array}$ & Yes \\
\hline $\begin{array}{l}\text { Cryptophytes } \\
\text { (abundance) }\end{array}$ & Flow cytometry & $\begin{array}{l}\text { Rosette water } \\
\text { sample }\end{array}$ & Vaulot D. & Yes \\
\hline Delta ${ }^{18} \mathrm{O}-$ water & Mass Spectrometry & $\begin{array}{l}\text { Rosette water } \\
\text { sample }\end{array}$ & $\begin{array}{l}\text { Else B. / Mucci } \\
\text { A. }\end{array}$ & Yes \\
\hline $\begin{array}{l}\text { Demersal fish } \\
\text { diversity }\end{array}$ & Beam trawl & Fish trawl & Fortier L. & Yes \\
\hline Diacids (aerosol) & $\begin{array}{l}\text { High-performance anion exchange } \\
\text { chromatography with pulsed } \\
\text { amperometric detection (HPAEC- } \\
\text { PAD) }\end{array}$ & Atmosphere & $\begin{array}{l}\text { Panagiotopoulo } \\
\text { s C. / Sempere } \\
\text { R. }\end{array}$ & Yes \\
\hline Diatom (abundance) & Microscopy & $\begin{array}{l}\text { Rosette water } \\
\text { sample }\end{array}$ & Lafond A. & Yes \\
\hline
\end{tabular}




\begin{tabular}{|c|c|c|c|c|}
\hline $\begin{array}{l}\text { Diatom frustules } \\
\text { (abundance) }\end{array}$ & Ludox/colloidal silica extraction & Box corer & Morata N. & Yes \\
\hline $\begin{array}{l}\text { Diatoms } \\
\text { (Bacillariophyta) } \\
\text { abundance }\end{array}$ & Inverted microscopy & $\begin{array}{l}\text { Rosette water } \\
\text { sample }\end{array}$ & $\begin{array}{l}\text { Leblanc K. / } \\
\text { Quéguiner } \\
\text { B./Cornet V. }\end{array}$ & Yes \\
\hline $\begin{array}{l}\text { Diatoms } \\
\text { (Bacillariophyta) } \\
\text { taxonomy }\end{array}$ & Inverted microscopy & $\begin{array}{l}\text { Rosette water } \\
\text { sample }\end{array}$ & $\begin{array}{l}\text { Leblanc K. / } \\
\text { Quéguiner } \\
\text { B./Cornet V. }\end{array}$ & Yes \\
\hline $\begin{array}{l}\text { Diffuse attenuation } \\
\text { coefficient }(K d)\end{array}$ & C-OPS & $\begin{array}{l}\text { In-water } \\
\text { profiler }\end{array}$ & Belanger S. & Yes \\
\hline $\begin{array}{l}\text { Dimethyl sulfide } \\
\text { (DMS) }\end{array}$ & $\begin{array}{l}\text { Gas Chromatography-Mass } \\
\text { Spectrometry }\end{array}$ & $\begin{array}{l}\text { Rosette water } \\
\text { sample }\end{array}$ & $\begin{array}{l}\text { Masse G. / Gali } \\
\text { M. }\end{array}$ & Yes \\
\hline $\begin{array}{l}\text { Dimethyl sulfide (sea- } \\
\text { air flux) }\end{array}$ & $\begin{array}{l}\text { Gas Chromatography-Mass } \\
\text { Spectrometry }\end{array}$ & $\begin{array}{l}\text { Rosette water } \\
\text { sample }\end{array}$ & $\begin{array}{l}\text { Masse G. / Gali } \\
\text { M. }\end{array}$ & Yes \\
\hline $\begin{array}{l}\text { Dimethylsulfoniopropi } \\
\text { onate (DMSP) }\end{array}$ & $\begin{array}{l}\text { Gas Chromatography-Mass } \\
\text { Spectrometry }\end{array}$ & $\begin{array}{l}\text { Rosette water } \\
\text { sample }\end{array}$ & $\begin{array}{l}\text { Masse G. / Gali } \\
\text { M. / Lizotte M. } \\
\text { / Hussherr R. }\end{array}$ & Yes \\
\hline $\begin{array}{l}\text { Dissolved inorganic } \\
\text { carbon }(D I C)\end{array}$ & Coulometry & $\begin{array}{l}\text { Rosette water } \\
\text { sample }\end{array}$ & $\begin{array}{l}\text { Else B. / Miller } \\
\text { L. }\end{array}$ & Yes \\
\hline $\begin{array}{l}\text { Dissolved organic } \\
\text { carbon (HTOC) }\end{array}$ & $\begin{array}{l}\text { High temperature catalytic oxidation } \\
\text { (HTCO) }\end{array}$ & $\begin{array}{l}\text { Rosette water } \\
\text { sample }\end{array}$ & $\begin{array}{l}\text { Panagiotopoulo } \\
\text { s C. / Sempere } \\
\text { R. }\end{array}$ & Yes \\
\hline $\begin{array}{l}\text { Dissolved organic } \\
\text { carbon (DOC) }\end{array}$ & Wet oxidation & $\begin{array}{l}\text { Rosette Deck } \\
\text { incubations }\end{array}$ & $\begin{array}{l}\text { Raimbault P. / } \\
\text { Garcia N. }\end{array}$ & Yes \\
\hline $\begin{array}{l}\text { Dissolved organic } \\
\text { matter (sugars) }\end{array}$ & HPAEC-PAD & $\begin{array}{l}\text { Rosette water } \\
\text { sample }\end{array}$ & $\begin{array}{l}\text { Panagiotopoulo } \\
\text { s C. / Sempere } \\
\text { R. }\end{array}$ & Yes \\
\hline $\begin{array}{l}\text { Dissolved organic } \\
\text { nitrogen }\end{array}$ & Wet oxidation & $\begin{array}{l}\text { Rosette Deck } \\
\text { incubations }\end{array}$ & $\begin{array}{l}\text { Raimbault P. / } \\
\text { Garcia N. }\end{array}$ & Yes \\
\hline $\begin{array}{l}\text { Dissolved organic } \\
\text { nitrogen (release) }\end{array}$ & Isotopic procedure & $\begin{array}{l}\text { Rosette Deck } \\
\text { incubations }\end{array}$ & $\begin{array}{l}\text { Raimbault P. / } \\
\text { Garcia N. }\end{array}$ & Yes \\
\hline $\begin{array}{l}\text { Dissolved oxygen } \\
\text { concentration }\end{array}$ & SBE 43 & $\begin{array}{l}\text { In-water } \\
\text { profiler }\end{array}$ & $\begin{array}{l}\text { Guillot P. / } \\
\text { Gombault C. }\end{array}$ & Yes \\
\hline $\begin{array}{l}\text { Dissolved oxygen } \\
\text { concentration }\end{array}$ & Bio-Argo profiler & $\begin{array}{l}\text { In-water } \\
\text { profiler }\end{array}$ & Babin M. & Yes \\
\hline $\begin{array}{l}\text { Downward longwave } \\
\text { radiation }\end{array}$ & Pyrgeometer & Atmosphere & $\begin{array}{l}\text { Else B. / } \\
\text { Burgers T. }\end{array}$ & Yes \\
\hline
\end{tabular}




\begin{tabular}{|c|c|c|c|c|}
\hline $\begin{array}{l}\text { Downward shortwave } \\
\text { radiation }\end{array}$ & Pyranometer & Atmosphere & $\begin{array}{l}\text { Else B. / } \\
\text { Burgers T. }\end{array}$ & Yes \\
\hline $\begin{array}{l}\text { Downwelling } \\
\text { irradiance }(E d(z))\end{array}$ & C-OPS & $\begin{array}{l}\text { In-water } \\
\text { profiler }\end{array}$ & Belanger S. & Yes \\
\hline $\begin{array}{l}\text { Downwelling } \\
\text { irradiance above the } \\
\text { surface }(E d(0+))\end{array}$ & HyperSAS & $\begin{array}{l}\text { Above-water } \\
\text { sensor }\end{array}$ & Belanger S. & Yes \\
\hline $\begin{array}{l}\text { Downwelling } \\
\text { irradiance above the } \\
\text { surface }(E d(0+))\end{array}$ & $\begin{array}{l}\text { Santa Barbara DISORT atmospheric } \\
\text { radiative transfer (SBDART) model }\end{array}$ & Surface mode & $\begin{array}{l}\text { Babin M. / Gali } \\
\text { M. }\end{array}$ & Yes \\
\hline $\begin{array}{l}\text { Downwelling } \\
\text { irradiance above the } \\
\text { surface }(E d(0+))\end{array}$ & C-OPS & $\begin{array}{l}\text { In-water } \\
\text { profiler }\end{array}$ & Belanger S. & Yes \\
\hline $\begin{array}{l}\text { Downwelling } \\
\text { radiance }(\operatorname{Ed}(z))\end{array}$ & Bio-Argo profiler & $\begin{array}{l}\text { In-water } \\
\text { profiler }\end{array}$ & Babin M. & Yes \\
\hline $\begin{array}{l}\text { Epibenthic fauna } \\
\text { abundance }\end{array}$ & Microscopy & Agassiz trawl & Archambault P. & Yes \\
\hline $\begin{array}{l}\text { Epibenthic fauna } \\
\text { biomass }\end{array}$ & Wet weight & Agassiz trawl & Archambault P. & Yes \\
\hline $\begin{array}{l}\text { Epibenthic fauna } \\
\text { diversity }\end{array}$ & Microscopy & Agassiz trawl & Archambault P. & Yes \\
\hline Eukaryotic diversity & 18S rDNA amplicon sequencing & $\begin{array}{l}\text { Rosette water } \\
\text { sample }\end{array}$ & Vaulot D. & Yes \\
\hline $\begin{array}{l}\text { Fish abundance } \\
\text { (midwater) }\end{array}$ & Isaacs-Kidd midwater trawl (IKMT) & Fish trawl & Fortier L. & Yes \\
\hline $\begin{array}{l}\text { Lipid biomarker } \\
\text { concentration }\end{array}$ & GC-MS & $\begin{array}{l}\text { Collected } \\
\text { Organisms } \\
\text { (bird) }\end{array}$ & $\begin{array}{l}\text { Mosbech A. / } \\
\text { Fort J. }\end{array}$ & Yes \\
\hline Microturbulence & $\begin{array}{l}\text { Self-contained autonomous } \\
\text { microprofiler (SCAMP) }\end{array}$ & $\begin{array}{l}\text { In-water } \\
\text { profiler }\end{array}$ & $\begin{array}{l}\text { Vladoiu A. / } \\
\text { Dumont D. }\end{array}$ & Yes \\
\hline $\begin{array}{l}\text { Photosynthetic } \\
\text { nanoeukaryotes } \\
\text { (abundance) }\end{array}$ & Flow cytometry & $\begin{array}{l}\text { Rosette water } \\
\text { sample }\end{array}$ & Vaulot D. & Yes \\
\hline $\begin{array}{l}\text { Nitrate }\left(\mathrm{NO}_{3}^{-}\right) \\
\text {assimilation }\end{array}$ & Isotopic dilution ${ }^{15} \mathrm{~N}$ & $\begin{array}{l}\text { Rosette Deck } \\
\text { incubations }\end{array}$ & $\begin{array}{l}\text { Raimbault P. / } \\
\text { Garcia N. }\end{array}$ & Yes \\
\hline $\begin{array}{l}\text { Nitrate concentration } \\
\left(\mathrm{NO}_{3}^{-}\right)\end{array}$ & Colorimetry/Autoanalyzer & $\begin{array}{l}\text { Rosette water } \\
\text { sample }\end{array}$ & Tremblay J. E. & Yes \\
\hline
\end{tabular}




\begin{tabular}{|c|c|c|c|c|}
\hline $\begin{array}{l}\text { Nitrate concentration } \\
\left(\mathrm{NO}_{3}^{-}\right)\end{array}$ & Colorimetry/Autoanalyzer & $\begin{array}{l}\text { Rosette Deck } \\
\text { incubations }\end{array}$ & Garcia N. & Yes \\
\hline $\begin{array}{l}\text { Nitrate concentration } \\
\left(\mathrm{NO}_{3}^{-}\right)\end{array}$ & Bio-Argo profiler & $\begin{array}{l}\text { In-water } \\
\text { profiler }\end{array}$ & Babin M. & Yes \\
\hline $\begin{array}{l}\text { Nitrate concentration } \\
\left(\mathrm{NO}_{3}^{-}\right)\end{array}$ & MBARI-ISUS & $\begin{array}{l}\text { In-water } \\
\text { profiler }\end{array}$ & $\begin{array}{l}\text { Guillot P./ } \\
\text { Gombault C. }\end{array}$ & Yes \\
\hline Nitrification & ${ }^{15} \mathrm{~N}$ labeling & $\begin{array}{l}\text { Rosette Deck } \\
\text { incubations }\end{array}$ & $\begin{array}{l}\text { Raimbault P. / } \\
\text { Garcia N. }\end{array}$ & Yes \\
\hline $\begin{array}{l}\text { Nitrite concentration } \\
\left(\mathrm{NO}_{2}^{-}\right)\end{array}$ & Colorimetry/Autoanalyzer & Rosette & Tremblay J. E. & Yes \\
\hline $\begin{array}{l}\text { Nitrite concentration } \\
\left(\mathrm{NO}_{2}^{-}\right)\end{array}$ & Colorimetry/Autoanalyzer & $\begin{array}{l}\text { Rosette Deck } \\
\text { incubations }\end{array}$ & Garcia N. & Yes \\
\hline $\begin{array}{l}\text { Benthic nitrogen } \\
\text { content }\end{array}$ & $\mathrm{CN}$ analyser & Box corer & Morata N. & Yes \\
\hline Open water days & $\begin{array}{l}\text { Advanced microwave scanning } \\
\text { radiometer (AMSR) }\end{array}$ & Satellite & $\begin{array}{l}\text { Massicotte P. / } \\
\text { Ferland J. }\end{array}$ & Yes \\
\hline $\begin{array}{l}\text { Particle size } \\
\text { distribution }\end{array}$ & Underwater vision profiler (UVP-5) & $\begin{array}{l}\text { In-water } \\
\text { vision } \\
\text { profiler }\end{array}$ & Picheral M. & Yes \\
\hline Particulate mass & Dry Weight & $\begin{array}{l}\text { Drifting } \\
\text { sediment trap }\end{array}$ & Lalande C. & Yes \\
\hline $\begin{array}{l}\text { Particulate nitrogen } \\
\text { content }\end{array}$ & Elemental analyzer & $\begin{array}{l}\text { Drifting } \\
\text { sediment trap }\end{array}$ & Lalande C. & Yes \\
\hline $\begin{array}{l}\text { Particulate organic } \\
\text { carbon (POC) }\end{array}$ & Elemental analyzer & $\begin{array}{l}\text { Rosette water } \\
\text { sample }\end{array}$ & $\begin{array}{l}\text { Bruyant F. / } \\
\text { Lariviere J. / } \\
\text { Babin M. }\end{array}$ & Yes \\
\hline $\begin{array}{l}\text { Particulate organic } \\
\text { carbon (POC) }\end{array}$ & High combustion & $\begin{array}{l}\text { Rosette Deck } \\
\text { incubations }\end{array}$ & $\begin{array}{l}\text { Raimbault P. / } \\
\text { Garcia N. }\end{array}$ & Yes \\
\hline $\begin{array}{l}\text { Particulate organic } \\
\text { carbon (POC) }\end{array}$ & Elemental analyzer & $\begin{array}{l}\text { Drifting } \\
\text { sediment trap }\end{array}$ & Lalande C. & Yes \\
\hline $\begin{array}{l}\text { Particulate organic } \\
\text { nitrogen }(P O N)\end{array}$ & Elemental analyzer & $\begin{array}{l}\text { Rosette water } \\
\text { sample }\end{array}$ & $\begin{array}{l}\text { Bruyant F. / } \\
\text { Lariviere J. / } \\
\text { Babin M. }\end{array}$ & Yes \\
\hline $\begin{array}{l}\text { Particulate organic } \\
\text { nitrogen (PON) }\end{array}$ & High combustion & $\begin{array}{l}\text { Rosette Deck } \\
\text { incubations }\end{array}$ & $\begin{array}{l}\text { Raimbault P. / } \\
\text { Garcia N. }\end{array}$ & Yes \\
\hline
\end{tabular}




\begin{tabular}{|c|c|c|c|c|}
\hline PDMPO uptake & $\begin{array}{l}\text { Spectrophotometry/Spectrofluorome } \\
\text { try }\end{array}$ & $\begin{array}{l}\text { Rosette water } \\
\text { sample }\end{array}$ & $\begin{array}{l}\text { Leblanc K. / } \\
\text { Quéguiner } \\
\text { B./Cornet V. }\end{array}$ & Yes \\
\hline $\begin{array}{l}\text { Phosphate } \\
\left.\text { concentration }\left(\mathrm{PO}_{4}\right)^{3-}\right)\end{array}$ & Colorimetry/Autoanalyzer & $\begin{array}{l}\text { Rosette water } \\
\text { sample }\end{array}$ & Tremblay J. E. & Yes \\
\hline $\begin{array}{l}\text { Phosphate } \\
\left.\text { concentration }\left(\mathrm{PO}_{4}\right)^{3-}\right)\end{array}$ & Colorimetry/Autoanalyzer & $\begin{array}{l}\text { Rosette Deck } \\
\text { incubations }\end{array}$ & Garcia N. & Yes \\
\hline $\begin{array}{l}\text { Photosynthetic } \\
\text { eukaryotes } \\
\text { (morphology) }\end{array}$ & Scanning Electron Microscopy & $\begin{array}{l}\text { Rosette water } \\
\text { sample }\end{array}$ & Vaulot D. & Yes \\
\hline $\begin{array}{l}\text { Photosynthetic } \\
\text { available radiation } \\
(P A R)\end{array}$ & QCP-2300 & $\begin{array}{l}\text { In-water } \\
\text { profiler }\end{array}$ & $\begin{array}{l}\text { Guillot P. / } \\
\text { Gombault C. }\end{array}$ & Yes \\
\hline $\begin{array}{l}\text { Photosynthetic } \\
\text { available radiation } \\
(P A R)\end{array}$ & C-OPS & $\begin{array}{l}\text { In-water } \\
\text { profiler }\end{array}$ & Belanger S. & Yes \\
\hline $\begin{array}{l}\text { Photosynthetic } \\
\text { available radiation } \\
(P A R)\end{array}$ & SBDART & Surface mode & $\begin{array}{l}\text { Babin M. / Gali } \\
\text { M. }\end{array}$ & Yes \\
\hline $\begin{array}{l}\text { Photosynthetic } \\
\text { available radiation } \\
(P A R)\end{array}$ & Above surface radiometer & Atmosphere & $\begin{array}{l}\text { Else B. / } \\
\text { Burgers T. }\end{array}$ & Yes \\
\hline $\begin{array}{l}\text { Photosynthetic } \\
\text { available radiation } \\
(P A R)\end{array}$ & Bio-Argo profiler & $\begin{array}{l}\text { In-water } \\
\text { profiler }\end{array}$ & Babin M. & Yes \\
\hline $\begin{array}{l}\text { Photosynthetic } \\
\text { parameters }\end{array}$ & ${ }^{14} \mathrm{C}$ P vs. E curve & $\begin{array}{l}\text { Rosette water } \\
\text { sample }\end{array}$ & Lewis $\mathrm{K}$. & Yes \\
\hline $\begin{array}{l}\text { Phytoplankton } \\
\text { (taxonomy) }\end{array}$ & Inverted Microscopy & $\begin{array}{l}\text { Rosette water } \\
\text { sample }\end{array}$ & Babin M. & Yes \\
\hline $\begin{array}{l}\text { Phytoplankton } \\
\text { (micro-) taxonomy }\end{array}$ & Microscopy & $\begin{array}{l}\text { Drifting } \\
\text { sediment trap }\end{array}$ & Lalande C. & Yes \\
\hline $\begin{array}{l}\text { Phytoplankton } \\
\text { (taxonomy) }\end{array}$ & Imaging FlowCytobot & Sea ice core & $\begin{array}{l}\text { Bruyant F. / } \\
\text { Grondin P.L. / } \\
\text { Babin M. }\end{array}$ & Yes \\
\hline
\end{tabular}




\begin{tabular}{|c|c|c|c|c|}
\hline $\begin{array}{l}\text { Phytoplankton } \\
\text { (taxonomy) }\end{array}$ & Imaging FlowCytobot & $\begin{array}{l}\text { Rosette water } \\
\text { sample }\end{array}$ & $\begin{array}{l}\text { Bruyant F. / } \\
\text { Grondin P.L. / } \\
\text { Babin M. }\end{array}$ & Yes \\
\hline $\begin{array}{l}\text { Phytoplankton } \\
\text { cultures }\end{array}$ & $\begin{array}{l}\text { Sorted by flow cytometry, serial } \\
\text { dilution, single cell pipetting }\end{array}$ & $\begin{array}{l}\text { Rosette water } \\
\text { sample }\end{array}$ & Vaulot D. & Yes \\
\hline $\begin{array}{l}\text { Photosynthetic } \\
\text { picoeukaryotes } \\
\text { (abundance) }\end{array}$ & Flow cytometry & $\begin{array}{l}\text { Rosette water } \\
\text { sample }\end{array}$ & Vaulot D. & Yes \\
\hline $\begin{array}{l}\text { Pigments } \\
\text { concentration }\end{array}$ & HPLC & $\begin{array}{l}\text { Rosette water } \\
\text { sample }\end{array}$ & $\begin{array}{l}\text { Ras J. / } \\
\text { Claustre H. / } \\
\text { Dimier C. }\end{array}$ & Yes \\
\hline $\begin{array}{l}\text { Pigment } \\
\text { concentration }\end{array}$ & HPLC & Sea ice core & $\begin{array}{l}\text { Ras J. / } \\
\text { Claustre H. / } \\
\text { Dimier C. }\end{array}$ & Yes \\
\hline Plankton taxonomy & UVP-5 & $\begin{array}{l}\text { In-water } \\
\text { profiler }\end{array}$ & Picheral M. & Yes \\
\hline Primary production & ${ }^{13} \mathrm{C}$ labeling & $\begin{array}{l}\text { Rosette Deck } \\
\text { incubations }\end{array}$ & $\begin{array}{l}\text { Raimbault P. / } \\
\text { Garcia N. }\end{array}$ & Yes \\
\hline $\begin{array}{l}\text { Quantum efficiency of } \\
\text { PSII (Fv/Fm) } \\
\text { (phytoplankton) }\end{array}$ & $\begin{array}{l}\text { Benchtop pulse amplified } \\
\text { modulated fluorometer (PAM) - } \\
\text { PhytoPAM }\end{array}$ & $\begin{array}{l}\text { Rosette water } \\
\text { sample }\end{array}$ & Joy-Warren H. & Yes \\
\hline Salinity & Salinometer & $\begin{array}{l}\text { Rosette water } \\
\text { sample }\end{array}$ & Pascal Guillot & Yes \\
\hline $\begin{array}{l}\text { Seabird diversity and } \\
\text { abundance }\end{array}$ & Visual observation & On way & $\begin{array}{l}\text { Anders } \\
\text { Mosbech }\end{array}$ & Yes \\
\hline Sea ice concentration & Satellite & Surface mode & Massicotte P. & Yes \\
\hline Silica biogenic (BSi) & BSi extraction & $\begin{array}{l}\text { Rosette water } \\
\text { sample }\end{array}$ & $\begin{array}{l}\text { Leblanc } \\
\text { K./Quéguiner } \\
\text { B./Leynaert } \\
\text { A./Moriceau } \\
\text { B./Legras } \\
\text { J./Gallinari M. }\end{array}$ & Yes \\
\hline $\begin{array}{l}\text { Silica biogenic }(B S i) \\
\text { dissolution rate }\end{array}$ & Dissolution in filtered sea water & $\begin{array}{l}\text { Rosette water } \\
\text { sample }\end{array}$ & $\begin{array}{l}\text { Moriceau } \\
\text { B./Gallinari M. }\end{array}$ & Yes \\
\hline $\begin{array}{l}\text { Silica biogenic } \\
\text { concentration }\end{array}$ & BSi extraction & Box corer & $\begin{array}{l}\text { Morata } \\
\text { N./Gallinari M. }\end{array}$ & Yes \\
\hline
\end{tabular}




\begin{tabular}{|c|c|c|c|c|}
\hline Silica lithogenic (LSi) & LSi extraction & $\begin{array}{l}\text { Rosette water } \\
\text { sample }\end{array}$ & $\begin{array}{l}\text { Leblanc } \\
\text { K./Quéguiner } \\
\text { B./Leynaert } \\
\text { A./Moriceau } \\
\text { B./Legras } \\
\text { J./Gallinari M. }\end{array}$ & Yes \\
\hline Silicate (uptake rate) & ${ }^{32} \mathrm{Si}$ absorption & $\begin{array}{l}\text { Rosette water } \\
\text { sample }\end{array}$ & $\begin{array}{l}\text { Leynaert A./ } \\
\text { Quéguiner } \\
\text { B./Gallinari M. }\end{array}$ & Yes \\
\hline $\begin{array}{l}\text { Silicate concentration } \\
\left(\mathrm{Si}(\mathrm{OH})_{4}\right)\end{array}$ & Colorimetry/Autoanalyzer & $\begin{array}{l}\text { Rosette water } \\
\text { sample }\end{array}$ & Tremblay J. E. & Yes \\
\hline $\begin{array}{l}\text { Silicate concentration } \\
\left(\mathrm{Si}(\mathrm{OH})_{4}\right)\end{array}$ & Colorimetry/Autoanalyzer & $\begin{array}{l}\text { Rosette Deck } \\
\text { incubations }\end{array}$ & Garcia N. & Yes \\
\hline $\begin{array}{l}\text { Silicate concentration } \\
\left(\mathrm{Si}(\mathrm{OH})_{4}\right)\end{array}$ & Colorimetry/Autoanalyzer & $\begin{array}{l}\text { Rosette water } \\
\text { sample }\end{array}$ & $\begin{array}{l}\text { Leynaert A. / } \\
\text { Moriceau } \\
\text { B./Gallinari M. }\end{array}$ & Yes \\
\hline $\begin{array}{l}\text { Silicate }\left(\mathrm{Si}(\mathrm{OH})_{4}\right)- \\
\text { absorption kinetics }\end{array}$ & ${ }^{32} \mathrm{Si}$ absorption - incubation & $\begin{array}{l}\text { Rosette water } \\
\text { sample }\end{array}$ & $\begin{array}{l}\text { Leynaert A./ } \\
\text { Quéguiner } \\
\text { B./Gallinari M. }\end{array}$ & Yes \\
\hline Sub-bottom profiles & 320 sub-bottom echosounder & $\begin{array}{l}\text { Continuous } \\
\text { horizontal }\end{array}$ & $\begin{array}{l}\text { Lajeunesse P. / } \\
\text { Joyal G. / } \\
\text { Brouard E. }\end{array}$ & Yes \\
\hline Sugars (aerosol) & HPAEC-PAD & Atmosphere & $\begin{array}{l}\text { Panagiotopoulo } \\
\text { s C. / Sempere } \\
\text { R. }\end{array}$ & Yes \\
\hline $\begin{array}{l}\text { Suspended particulate } \\
\text { material (SPM) }\end{array}$ & Particle dry weight (gravimetry) & $\begin{array}{l}\text { Rosette water } \\
\text { sample }\end{array}$ & $\begin{array}{l}\text { Bruyant F. / } \\
\text { Lariviere J. / } \\
\text { Babin M. }\end{array}$ & Yes \\
\hline $\begin{array}{l}\text { Synechococcus } \\
\text { (abundance) }\end{array}$ & Flow cytometry & $\begin{array}{l}\text { Rosette water } \\
\text { sample }\end{array}$ & Vaulot D. & Yes \\
\hline Total alkalinity (TA) & Potentiometry & $\begin{array}{l}\text { Rosette water } \\
\text { sample }\end{array}$ & $\begin{array}{l}\text { Else B. / Miller } \\
\text { L. }\end{array}$ & Yes \\
\hline $\begin{array}{l}\text { Total organic carbon } \\
\text { (TOC) }\end{array}$ & Wet oxidation & $\begin{array}{l}\text { Rosette Deck } \\
\text { incubations }\end{array}$ & $\begin{array}{l}\text { Raimbault P. / } \\
\text { Garcia N. }\end{array}$ & Yes \\
\hline $\begin{array}{l}\text { Total organic nitrogen } \\
(T O N)\end{array}$ & Wet oxidation & $\begin{array}{l}\text { Rosette Deck } \\
\text { incubations }\end{array}$ & $\begin{array}{l}\text { Raimbault P. / } \\
\text { Garcia N. }\end{array}$ & Yes \\
\hline $\begin{array}{l}\text { Total organic } \\
\text { phosphorus (TOP) }\end{array}$ & Wet oxidation & $\begin{array}{l}\text { Rosette Deck } \\
\text { incubations }\end{array}$ & $\begin{array}{l}\text { Raimbault P. / } \\
\text { Garcia N. }\end{array}$ & Yes \\
\hline
\end{tabular}




\begin{tabular}{|c|c|c|c|c|}
\hline $\begin{array}{l}\text { Transmittance (of } \\
\text { light in water) }\end{array}$ & CST & $\begin{array}{l}\text { Moving } \\
\text { Vessel } \\
\text { Profiler }\end{array}$ & $\begin{array}{l}\text { Morisset S. / } \\
\text { Gombault C. }\end{array}$ & Yes \\
\hline $\begin{array}{l}\text { Transmittance (of } \\
\text { light in water) }\end{array}$ & C-Star & $\begin{array}{l}\text { In-water } \\
\text { profiler }\end{array}$ & $\begin{array}{l}\text { Guillot P./ } \\
\text { Gombault C. }\end{array}$ & Yes \\
\hline $\begin{array}{l}\text { Upwelling irradiance } \\
(E u(z))\end{array}$ & C-OPS & $\begin{array}{l}\text { In-water } \\
\text { profiler }\end{array}$ & Belanger S. & Yes \\
\hline $\begin{array}{l}\text { Upwelling radiance } \\
\text { (Lu) }\end{array}$ & C-OPS & $\begin{array}{l}\text { In-water } \\
\text { profiler }\end{array}$ & Belanger S. & Yes \\
\hline $\begin{array}{l}\text { Variable fluorescence } \\
\text { and rapid light curves } \\
\text { parameters } \\
\text { (phytoplankton) }\end{array}$ & Benchtop PAM & $\begin{array}{l}\text { Rosette water } \\
\text { sample }\end{array}$ & Joy-Warren H. & Yes \\
\hline $\begin{array}{l}\text { Weather and } \\
\text { navigation }\end{array}$ & On Board & AVOS & $\begin{array}{l}\text { Morisset S. / } \\
\text { Gombault C. }\end{array}$ & Yes \\
\hline Wind direction & Wind monitor & $\begin{array}{l}\text { Meteorologic } \\
\text { al Tower }\end{array}$ & $\begin{array}{l}\text { Else B. / } \\
\text { Burgers T. }\end{array}$ & Yes \\
\hline Wind speed & Wind monitor & $\begin{array}{l}\text { Meteorologic } \\
\text { al Tower }\end{array}$ & $\begin{array}{l}\text { Else B. / } \\
\text { Burgers T. }\end{array}$ & Yes \\
\hline Wind speed & $\begin{array}{l}\text { Cross Calibrated Multi Platform } \\
\text { (CCMP) }\end{array}$ & Atmosphere & Massicotte P. & Yes \\
\hline $\begin{array}{l}\text { Zooplankton } \\
\text { (abundance) }\end{array}$ & Multi nets (Hydrobios) & Plankton net & Fortier L. & Yes \\
\hline $\begin{array}{l}\text { Zooplankton } \\
\text { (abundances) }\end{array}$ & Vertical plankton net $200 \mu \mathrm{m}$ & Plankton net & Fortier L. & Yes \\
\hline $\begin{array}{l}\text { Zooplankton (meso-) } \\
\text { (abundance) }\end{array}$ & Tucker net & Plankton net & Fortier L. & Yes \\
\hline $\begin{array}{l}\text { Zooplankton (meso-) } \\
\text { (taxonomy) }\end{array}$ & Tucker net & Plankton net & Fortier L. & Yes \\
\hline $\begin{array}{l}\text { Zooplankton } \\
\text { (taxonomy) }\end{array}$ & Multi nets (Hydrobios) & Plankton net & Fortier L. & Yes \\
\hline $\begin{array}{l}\text { Zooplankton } \\
\text { (taxonomy) }\end{array}$ & Vertical plankton net $200 \mu \mathrm{m}$ & Plankton net & Fortier L. & Yes \\
\hline $\begin{array}{l}\text { Zooplankton } \\
\text { (taxonomy) }\end{array}$ & Microscopy & $\begin{array}{l}\text { Drifting } \\
\text { sediment trap }\end{array}$ & Lalande C. & Yes \\
\hline
\end{tabular}


https://doi.org/10.5194/essd-2022-41

Preprint. Discussion started: 21 February 2022

(c) Author(s) 2022. CC BY 4.0 License.

(c) (i)
Zooplankton fecal
pellets

Microscopy
Drifting

sediment trap
Lalande C. Yes 
https://doi.org/10.5194/essd-2022-41

Preprint. Discussion started: 21 February 2022

(c) Author(s) 2022. CC BY 4.0 License.

Table 4. Name and description of variables systematically included in data sets (i.e., in each .csv file)

Variable Description

\begin{tabular}{l|l}
\hline $\begin{array}{l}\text { mission } \\
\text { date }\end{array}$ & $\begin{array}{l}\text { mission identifier ("ice_camp_2016", "Amundsen_2016", ...) } \\
\text { sampling date (UTC) } \\
\text { latitude }\end{array}$ \\
longitude & $\begin{array}{l}\text { longitude of sampling (degree east decimals) } \\
\text { station }\end{array}$ \\
station name (ex: G206) \\
operation code \\
$\begin{array}{l}\text { GE_0008-1 (unique operation identifier) } \\
\text { name(s) of the principal investigator(s) responsible of the measured (calculated) } \\
\text { variable }\end{array}$
\end{tabular}

